\title{
Continuous measurements at the urban roadside in an Asian megacity by Aerosol Chemical Speciation Monitor (ACSM): particulate matter characteristics during fall and winter seasons in Hong Kong
}

\author{
C. Sun ${ }^{1}$, B. P. Lee ${ }^{1}$, D. Huang ${ }^{2}$, Y. Jie Li ${ }^{3}$, M. I. Schurman ${ }^{1}$, P. K. K. Louie ${ }^{4}$, C. Luk ${ }^{4}$, and C. K. Chan ${ }^{1,2,5}$ \\ ${ }^{1}$ Division of Environment, Hong Kong University of Science and Technology, Kowloon, Hong Kong, China \\ ${ }^{2}$ Department of Chemical and Biomolecular Engineering, Hong Kong University of Science and Technology, \\ Kowloon, Hong Kong, China \\ ${ }^{3}$ Faculty of Science and Technology, University of Macau, Taipa, Macau, China \\ ${ }^{4}$ Hong Kong Environmental Protection Department, Wan Chai, Hong Kong, China \\ ${ }^{5}$ School of Energy and Environment, City University of Hong Kong, Hong Kong, China
}

Correspondence to: C. K. Chan (chak.k.chan@cityu.edu.hk)

Received: 2 June 2015 - Published in Atmos. Chem. Phys. Discuss.: 16 July 2015

Revised: 13 January 2016 - Accepted: 15 January 2016 - Published: 15 February 2016

\begin{abstract}
Non-refractory submicron aerosol is characterized using an Aerosol Chemical Speciation Monitor (ACSM) in the fall and winter seasons of 2013 on the roadside in an Asian megacity environment in Hong Kong. Organic aerosol (OA), characterized by application of Positive Matrix Factorization (PMF), and sulfate are found to be dominant. Trafficrelated organic aerosol shows good correlation with other vehicle-related species, and cooking aerosol displays clear mealtime concentration maxima and association with surface winds from restaurant areas. Contributions of individual species and OA factors to high NR-PM ${ }_{1}$ are analyzed for hourly data and daily data; while cooking emissions in OA contribute to high hourly concentrations, particularly during mealtimes, secondary organic aerosol components are responsible for episodic events and high day-to-day PM concentrations. Clean periods are either associated with precipitation, which reduces secondary OA with a lesser impact on primary organics, or clean oceanic air masses with reduced long-range transport and better dilution of local pollution. Haze events are connected with increases in contribution of secondary organic aerosol, from 30 to $50 \%$ among total non-refractory organics, and the influence of continental air masses.
\end{abstract}

\section{Introduction}

The Special Administrative Region of Hong Kong is a global logistics and finance center located at the southeastern edge of the Pearl River Delta (PRD) region, China's largest manufacturing area and one of the world's most densely populated regions. Hong Kong has been plagued by deteriorating air quality, attributed to local emissions from traffic, residential and commercial activity, regional pollution from the PRD and long-range transport (Nie et al., 2013; Wong et al., 2013; Yuan et al., 2013).

High-time-resolution online instruments can characterize ambient aerosols quickly and mitigate the influence of changing environmental conditions. Few real-time studies have been conducted in Hong Kong aside from recent measurement campaigns conducted by high-resolution aerosol mass spectrometer (HR-AMS; Lee et al., 2013; Li et al., 2013, 2015; Huang et al., 2015). Long-term AMS studies tend to be costly and time-consuming due to the complexity of the instrument. The Aerosol Chemical Speciation Monitor (ACSM), whose design is based on the AMS but has been substantially simplified, has seen a growing trend of use due to its comparative ease of operation, robustness and sufficient time resolution $(\sim 20-60 \mathrm{~min})$ for studies spanning months or longer (Ng et al., 2011; Sun et al., 2012, 2013a, b; Bud- 
isulistiorini et al., 2013; Canonaco et al., 2013; Takahama et al., 2013; Bougiatioti et al., 2014; Petit et al., 2015; Ripoll et al., 2015; Tiitta et al., 2014; Minguillón et al., 2015).

Recently, a high-resolution aerosol mass spectrometer (HR-ToF-AMS) was applied at an urban site in the Shenzhen metropolitan area and a rural site in PRD region during October and November (He et al., 2011; Huang et al., 2011). They found that organic concentration dominates followed by sulfate, which is similar to this study, but the fraction of sulfate at the rural site is larger than that of the urban site. Four organic aerosol (OA) components were identified in urban site including hydrocarbon-like $\mathrm{OA}(\mathrm{HOA})$, biomass burning $\mathrm{OA}$ (BBOA), low-volatility oxygenated OA (LV-OOA) and semivolatile oxygenated OA (SV-OOA), but only three OA factors without HOA were resolved at the rural site. They both reported an important contribution from BBOA with about $24 \%$ of total OA.

We also have previously deployed HR-ToF-AMS at the supersite of the Hong Kong University of Science and Technology (HKUST) to determine typical variations in submicron species concentrations, overall composition, size distributions, PMF-resolved organic factors and degree of oxygenation. The supersite measurements provided valuable insights into characteristics of mainly of secondary components of submicron particulate matter, with dominance of sulfate and oxygenated organic aerosol species observed (Lee et al., 2013; Li et al., 2013, 2015). Subsequent work was conducted at a downtown location (Mong Kok, MK) in Hong Kong, next to the roadside, in spring 2013 to assess important primary aerosol sources in the inner-city to identify contributions of long-range transport to roadside pollution and to establish characteristic concentration trends at different temporal scales. Cooking aerosol was identified as the dominant component in submicron non-refractory organics, followed by traffic-related emissions (Lee et al., 2015).

Differentiate from previous studies in Hong Kong, this work focuses on the characterization of roadside aerosol during the fall and winter seasons, when the influence of transported air mass is greatest and PM pollution in Hong Kong generally more severe. Episodic haze events were found to be mainly driven by secondary aerosol rather than primary emissions, while hourly high PM concentrations were often driven by cooking aerosol. Statistical methods were employed to show that the correlation of cooking organic aerosol (COA) and HOA to SV-OOA varied under different conditions and period of a day. While HOA showed a stronger relationship to SV-OOA overall, COA can be an important contributor to SV-OOA during mealtimes.

\section{Experimental}

The roadside measurement data collected from 3 September to 31 December 2013 in MK, an urban area with dense buildings and population in the Kowloon peninsula under the
Hong Kong Environmental Protection Department (HKEPD) project (ref. 13-00986) were adopted. The sampling site was next to the roadside air quality monitoring station of HKEPD at the junction of the heavily trafficked Nathan Road and Lai Chi Kok Road $\left(22^{\circ} 19^{\prime} 2^{\prime \prime} \mathrm{N}, 114^{\circ} 10^{\prime} 06^{\prime \prime} \mathrm{E}\right)$. The distribution of businesses in the vicinity varies, with restaurants mainly to the east, commercial buildings to the south and east, small shops for interior decoration, furniture and electrical goods to the west and residential buildings to the north of the sampling location (Lee et al., 2015). The sampling setup is described in detail in the Supplement, Sect. S1.

Non-refractory $\mathrm{PM}_{1}\left(\mathrm{NR}-\mathrm{PM}_{1}\right)$ species (sulfate, nitrate, ammonium, chloride and organics) were measured in situ by an Aerodyne ACSM (SN: 140-154). Other data including meteorological data (wind, temperature, relative humidity, solar irradiation), volatile organic compounds (VOCs) measured by an online gas-chromatography system (GC955-611 and GC955-811, Synspec BV) and standard criteria pollutants $\left(\mathrm{NO}_{x}, \mathrm{SO}_{2}\right.$ and $\left.\mathrm{PM}_{2.5}\right)$ were provided by the HKEPD, with equipment details available from the HKEPD air quality reports (Chow, 2013).

The acquired 20-minute-average data were treated according to the general ACSM data analysis protocols established in previous studies (Ng et al., 2011; Sun et al., 2012), using the standard WaveMetrics Igor Pro based data analysis software (version 6.3.5.5) and incorporating calibrations for relative ionization efficiency, collection efficiency and detection limit. Further details on data treatment can be found in Sect. S2.

Factors contributing to organic aerosol were explored using PMF (Paatero and Tapper, 1994; Zhang et al., 2011) with the Igor Pro based PMF evaluation toolkit (PET; UIbrich et al., 2009). In general, PMF can be used to resolve factors as organic aerosol into HOA, COA, SV-OOA, LV-OOA and others. ME-2 analysis with the SOFI tool as applied in several studies may yield additional insights but has not been applied in this study due to its ongoing development (Canonaco et al., 2013; Minguillón et al., 2015). The optimal factor number was determined by inter-comparing factors' mass spectra and time series, correlations between factors and related tracers and correlations with standard mass spectra; solutions with three, four and five factors at $f$ peak $=0$ and six factors at $f$ peak $=-0.2$ were explored, after which the optimal $f$ peak value was determined by repeating the above analysis with varying $f$ peak values.

The four-factor solution (HOA, COA, SV-OOA, LV-OOA) is optimal, with $\mathrm{Q} / \mathrm{Q}_{\exp }=0.8$ and better differentiation between factor time series $\left(R_{\mathrm{pr}}<0.6\right.$; Fig. S6 in the Supplement). The factors also correlate well with associated inorganics and external tracers $\left(\mathrm{NO}_{3}, \mathrm{SO}_{4}, \mathrm{NH}_{4}, \mathrm{NO}_{x}\right.$; Zhang et al., 2005, 2011; Ulbrich et al., 2009), e.g., HOA with $\mathrm{NO}_{x}, \mathrm{SV}-\mathrm{OOA}$ with $\mathrm{NO}_{3}, \mathrm{LV}-\mathrm{OOA}$ with $\mathrm{SO}_{4}$ and $\mathrm{NH}_{4}$ (Table S4 in the Supplement). Furthermore, the resolved mass spectra of four factors exhibit good similarity (all uncentered $\left.R\left(R_{\mathrm{uc}}\right)>0.80\right)$ with reference source mass spec- 


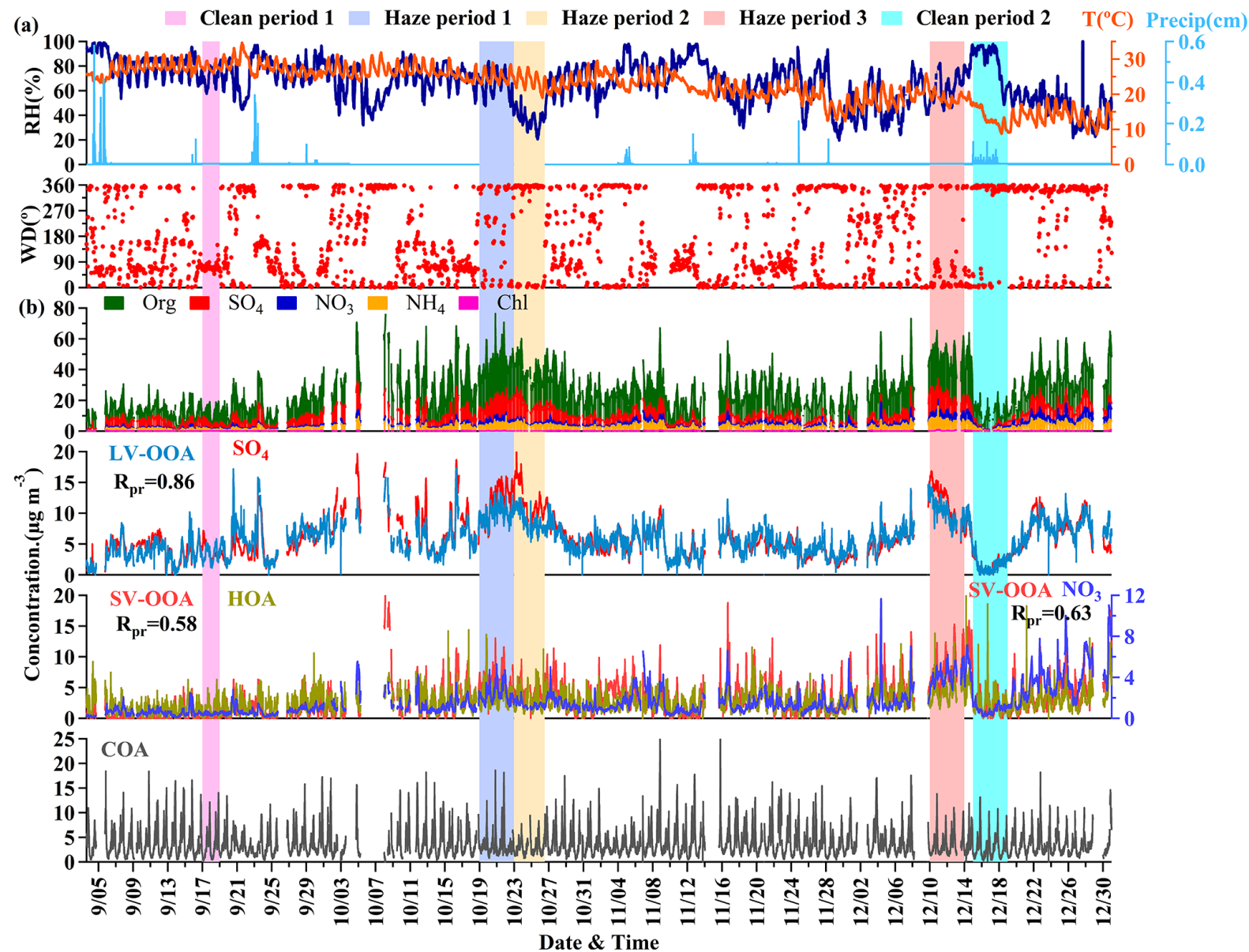

Figure 1. Overview of temporal variation of (a) meteorological factors (relative humidity, temperature and precipitation) and (b) stacked plot of non-refractory $\mathrm{PM}_{1}$ species $\left(\mathrm{Org}, \mathrm{SO}_{4}, \mathrm{NO}_{3}, \mathrm{NH}_{4}\right.$ and $\mathrm{Chl}$ ) and non-stacked plot of organic aerosol components (LV-OOA, SV-OOA, HOA and COA). Five periods - clean period $1(\mathrm{C} 1)$, haze period $1(\mathrm{H} 1)$, haze period $2(\mathrm{H} 2)$, haze period $3(\mathrm{H} 3)$ and clean period $2(\mathrm{C} 2)-$ are highlighted.

tra from the AMS MS database (Ulbrich, I. M., Lechner, M., and Jimenez, J. L., AMS Spectral Database, url: http: //cires.colorado.edu/jimenez-group/AMSsd; Ulbrich et al., 2009). PMF diagnostic details are shown in the Supplement (Sect. S3) and Fig. S7.

We note that $m / z 60$ and 73, important makers of BBOA mass spectra (Aiken et al., 2010; Cubision et al., 2011; Huang et al., 2011), were resolved not only in COA but also in SV-OOA. Their presence in SV-OOA is not the result of artifacts from the PMF analysis but was attributed to the following reasons, with more details shown in the Supplement (Sects. S4-6). Firstly, when PMF was run using only nighttime data (between 00:00 and 06:00; local time: UTC+8), i.e., when there is little COA (Fig. S10), these two ions still persist with similar fractional intensities in SV-OOA as at other times. Secondly, increasing the number of PMF factors and adjusting the $f$ peak value did not yield a distinct satisfactory BBOA factor. Thirdly, the time series of $m / z 60$ and 73 show weak correlation with other burning tracers
(EC_residual, CO_residual), with $R_{\text {pr }}$ of about 0.2 and 0.4 , respectively, but track well with SV-OOA, with $R_{\mathrm{pr}}$ of 0.92 and 0.93, respectively (Fig. S12, Table S9).

In terms of the possible sources of $m / z 60$ and 73, we observe that these two ions showed matching peaks with the COA diurnal profile and good correlations with the sum of the time series of COA and LV-OOA, with $R_{\mathrm{pr}}$ of 0.72 and 0.78 , respectively. Furthermore, the ratio of the integrated signal at $m / z 60$ to the total signal in the organic component mass spectrum is $0.48 \%$, which is just slightly higher than the baseline level $(0.3 \% \pm 0.06 \%)$ observed in environments without biomass burning influence and with secondary OA (SOA) dominance in ambient OA (Cubision et al., 2011). This indicates that these two ions at Mong Kok were mainly imbedded in cooking emissions and background aerosol due to transport rather than in a distinct source with further details shown in the Supplement (Sect. S6). The existence of $m / z 60$ and 73 in the emissions of Chinese cooking has been reported by He et al. (2010). Combustion of pulverized coal 
(a)

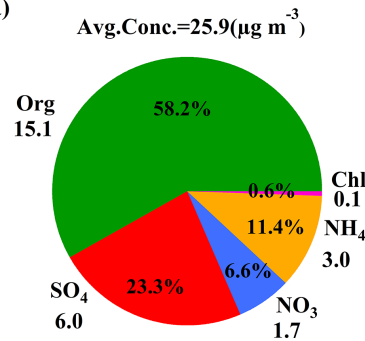

(b)

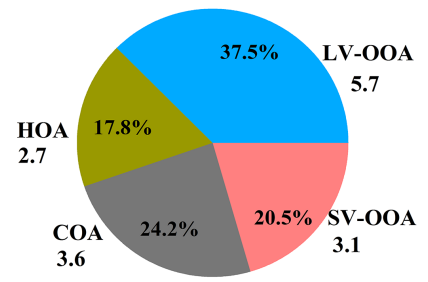

Figure 2. Average concentration of each chemical composition of (a) NR-PM 1 (Org, $\mathrm{SO}_{4}, \mathrm{NO}_{3}, \mathrm{NH}_{4}$ and $\left.\mathrm{Chl}\right)$ and (b) organic aerosol (LV-OOA, SV-OOA, HOA and COA).

for barbecue or hot pot rice is a potential additional source of these two ions (Wang et al., 2013). Additionally, the existence of transported $m / z 60$ and 73 indicates that SV-OOA at MK is potentially influenced by transported BBOA and coal combustion aerosol.

\section{Results and discussion}

\subsection{Mass concentration and chemical composition}

Figure 1a and $\mathrm{b}$ display meteorological data (relative humidity, temperature and precipitation) and mass concentrations of non-refractory $\mathrm{PM}_{1}\left(\mathrm{NR}-\mathrm{PM}_{1}\right)$ species and OA components, respectively, between September and December 2013. Total NR-PM ${ }_{1}$ concentrations vary from 2.1 to $76.4 \mu \mathrm{g} \mathrm{m}^{-3}$ with an average of $25.9 \pm 13.0 \mu \mathrm{g} \mathrm{m}^{-3}$. ACSM NR-PM 1 concentrations co-vary with that of $\mathrm{PM}_{2.5}$ measured by TEOM $\left(R^{2}=0.64\right.$, slope $=0.59 ;$ Fig. S1); the low slope value may be caused by the different size cuts of ACSM and TEOM and the presence of refractory materials such as elemental carbon (and to a lesser extent mineral dust and sea salt) which the ACSM cannot detect. Overall, daily $\mathrm{PM}_{2.5}$ concentrations range from 3.7 to $106.0 \mu \mathrm{g} \mathrm{m}^{-3}$ and are largely $(90.0 \%)$ within the $24 \mathrm{~h}$ air quality standard of $75 \mu \mathrm{g} \mathrm{m}^{-3}$ set by the Hong Kong Air Quality Objectives. Days with better air quality $\left(\mathrm{PM}_{2.5}<35 \mu \mathrm{g} \mathrm{m}^{-3}\right)$ are mainly observed in the month of September and in rainy periods of other months. The prevailing winds from the ocean in September not only bring in less polluted air mass but also dilute the local air pollutants compared with other seasons (Yuan et al., 2006; Li et al., 2015). Precipitation has an obvious impact on total NR-PM 1 concentrations but, as we will discuss, has a lesser effect on primary organics.

Overall, NR-PM $\mathrm{P}_{1}$ is dominated by organics and sulfate with relative contributions of 58.2 and $23.3 \%$ and average concentrations of $15.1 \pm 8.1$ and $6.0 \pm 3.5 \mu \mathrm{g} \mathrm{m}^{-3}$, respectively (Fig. 2a). Other inorganic species (ammonium, nitrate and chloride) amount to approximately $20 \%$ of NR-PM The dominance of organics and sulfate is consistent with previous online studies in urban areas (e.g., Salcedo et al.,
2006; Aiken et al., 2009; Sun et al., 2012, 2013b) as well as previous filter-based studies in MK (e.g., Louie et al., 2005; Cheng et al., 2010; Huang et al., 2014). The measured composition is consistent with earlier HR-AMS measurements carried out at the same site in spring and summer 2013 (Lee et al., 2015) with very similar overall species distribution but slightly lower measured concentrations as compared to the ACSM, likely due to the fact that sampling took place in different time periods (spring-summer 2013 for the AMS campaign, fall-winter 2013 for the ACSM campaign). In the AMS study, PMF aerosol factors were identified (one additional OOA factor and one additional COA factor). A marked difference is observed in the distribution of primary $\mathrm{OA}$ (POA) and SOA; whereas in spring and summer (AMS) POA makes up $65 \%$ of total organics, the reverse is observed for fall and winter (ACSM) when POA only amounts to $42 \%$ overall. A possible reason for this discrepancy is the fact that impacts of regional pollution and long-range transport are usually higher during fall and winter (Yuan et al., 2013; Li et al., 2015), thus contributing more SOA.

Elemental carbon (EC) concentrations are significant at the Mong Kok site but not measurable by ACSM due to its high refractory temperature. EC has been discussed extensively in the previously mentioned filter-based studies and a brief comparison of online elemental carbon/organic carbon (ECOC) measurements to the results of HR-AMS measurements has been presented in an HR-AMS study (Lee et al., 2015). We therefore do not discuss EC in detail in this work.

\subsection{OA Components}

PMF-resolved four factors, including two primary OA factors (HOA from traffic emissions and COA) and two OOAs: LV-OOA and the less-oxidized SV-OOA (Aiken et al., 2008; Jimenez et al., 2009; Tiitta et al., 2014). The mass spectra are depicted in Fig. 3. The mass concentration of primary OA factors (HOA and COA), a surrogate of local emissions, constitutes $42 \%$ of total organics and is slightly higher than that of LV-OOA ( $38 \%$; Fig. 2b). SV-OOA contributes approximately $20 \%$ to total OA and is associated with both the primary organic aerosol sources and LV-OOA (see Sect. 3.2).

\subsubsection{Hydrocarbon-like OA}

The mass spectrum of HOA is dominated by the $\mathrm{C}_{n} \mathrm{H}_{2 n-1}^{+}$ ion series $(m / z 27,41,55,69,83,97)$, typical of cycloalkanes or unsaturated hydrocarbon, which account for $27 \%$ of total peak intensity in the HOA spectrum. The other prominent group is the $\mathrm{C}_{n} \mathrm{H}_{2 n+1}^{+}$ion series $(m / z 29,43,57,71$, $85,99)$, typical of alkanes and accounting for $26 \%$ of the total peak. This mass spectrum is very similar to the standard HOA spectrum with $R_{\mathrm{uc}}$ of 0.92 , and its fractions of $\mathrm{C}_{n} \mathrm{H}_{2 n-1}^{+}$and $\mathrm{C}_{n} \mathrm{H}_{2 n+1}^{+}(27,26 \%)$ are consistent with standard ones $(=28,27 \%$; Ng et al., 2011). This HOA spectrum is also consistent with that resolved by HR-ToF-AMS at the 


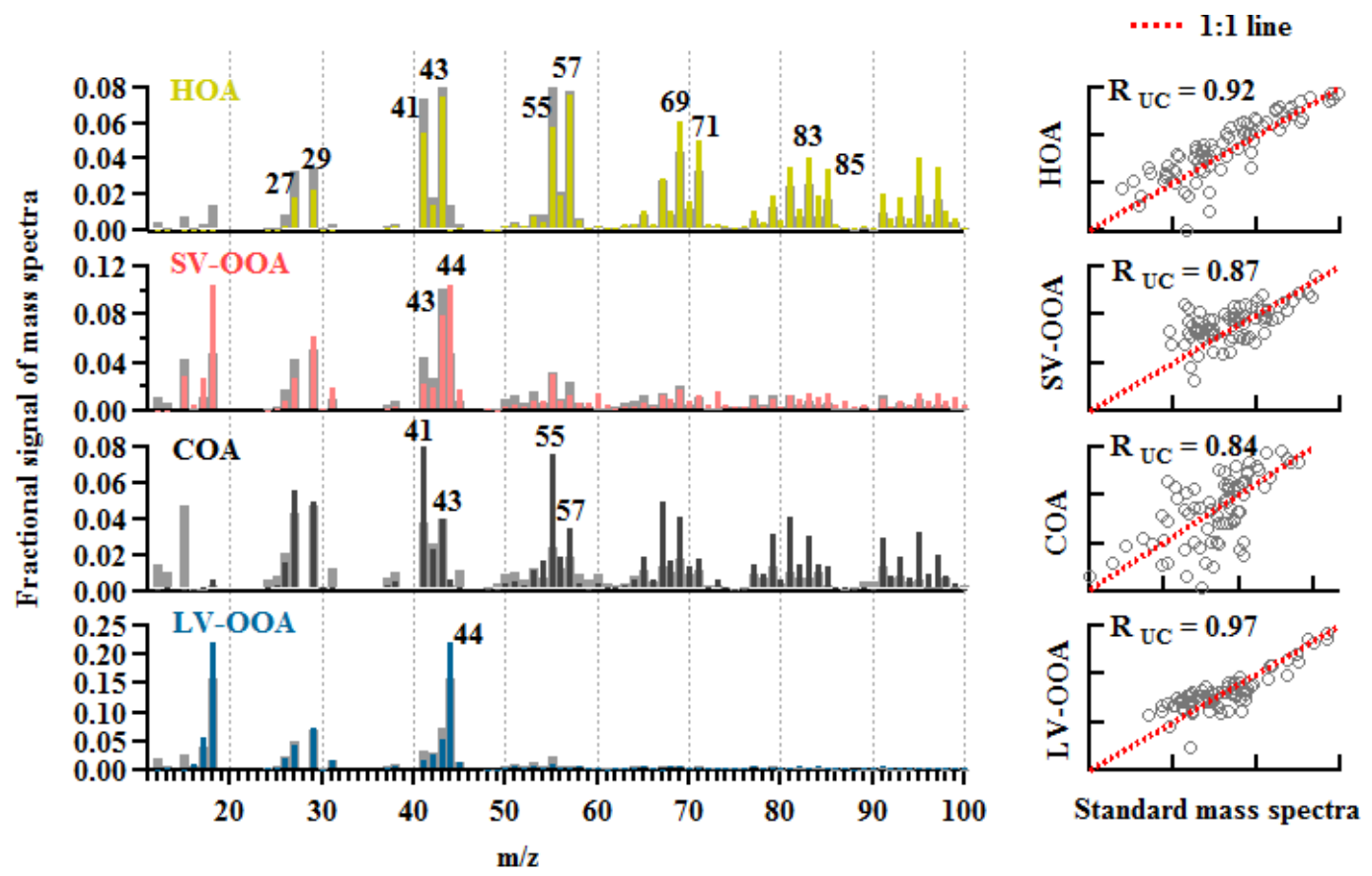

Figure 3. Mass spectra of resolved OA components (HOA, SV-OOA, LV-OOA, COA) with the corresponding standard spectra (in gray) and the correlation with standard mass spectral profiles available on the AMS MS database (Ulbrich, I. M., Lechner, M., and Jimenez, J. L., AMS Spectral Database). The $x$ and $y$ axes in the right-hand graphs are mass spectra of resolved factor and the standard, respectively.

HKUST supersite on the dominance of saturated CxHy-type ions, most notably at $m / z 43$ and 57 (Lee et al., 2013).

HOA has an average concentration of $2.7 \pm 0.98 \mu \mathrm{g} \mathrm{m}^{-3}$ (Fig. 1b) and shows strong diurnal variations, including a regular decrease to about $1 \mu \mathrm{g} \mathrm{m}^{-3}$ during 00:00-05:00 (Fig. 4h) which is discussed in Sect. 3.3 in detail. In addition, the temporal variation of HOA displays strong correlations with $\mathrm{NO}_{x}\left(R_{\mathrm{pr}}=0.69\right), \mathrm{CO}\left(R_{\mathrm{pr}}=0.62\right)$ and several VOCs (pentane, toluene, benzene) as shown in Table S10.

The diurnal patterns of vehicle numbers, $\mathrm{HOA}, \mathrm{NO}, \mathrm{NO}_{2}$, $\mathrm{NO}_{x}$ and traffic-related VOCs (i-pentane, $\mathrm{n}$-pentane, toluene, octane, benzene, i-butane and n-butane) are depicted in Fig. 5. Vehicle counting on Lai Chi Kok road next to the sampling site spanned 28-31 May 2013 and was provided by HKEPD (Lee et al., 2015). Although these dates are different from our campaign period, they provide a useful reference for the traffic conditions near the site. In general, more gasoline and diesel vehicles are observed during daytime than at night. The decrease of these vehicles during 22:00-04:00 is in agreement with the diurnal profile of HOA (Fig. 4h). However, liquefied petroleum gas (LPG) vehicles, which are usually taxis, show slightly higher numbers during 22:00-04:00 at the site. HOA increases sharply from $1.5 \mu \mathrm{g} \mathrm{m}^{-3}$ at about 06:00 to the morning peak of $3.6 \mu \mathrm{g} \mathrm{m}^{-3}$ at 09:00 and then persists at high concentrations until midnight, including another peak with $3.9 \mathrm{\mu g} \mathrm{m}^{-3}$ at 17:00. The diurnal pattern of $\mathrm{HOA}$ is consistent with that of $\mathrm{NO}_{x}\left(\mathrm{NO}+\mathrm{NO}_{2}\right)$, which is almost exclusively from vehicle emissions. These results are consistent with the traffic conditions at MK with heavy traffic continuously after 06:00 and rush hours from 07:00 to 11:00 and 16:00 to 19:00. $\mathrm{NO}_{2}$ is the result of direct emission as well as formation from $\mathrm{NO}$, and it increased during daytime to reach a maximum even higher than that of $\mathrm{NO}$ at about 17:00. Concentrations of toluene (a fuel additive) and pentane and octane (significant components in exhaust of petrol vehicles; Huang et al., 2011; Wanna et al., 2008) start to increase during the morning rush hour (07:00) and peak between 18:00 and 19:00. HOA and $\mathrm{NO}_{x}$ show a distinct morning peak at $\sim 08: 00$ when a small shoulder is also found in the VOCs. Butane, a constituent of LPG, displays a diurnal pattern different from that of HOA, with higher concentrations between 22:00 and 04:00; LPG-fueled taxis are a major means of transport during the nighttime and early morning, and fuel leakage during refueling may contribute to the observed pattern. Furthermore, fuel leakage during refueling of LPG vehicles may contribute more than diesel-fueled vehicular emissions to butane even though the number of diesel fueled vehicles is slightly higher than LPG ones at that time. At last, the sampling site is near a major junction serving a number of district centers (West Kowloon, Sha Tin, Tsim Sha Tsui) and is therefore frequented by taxis.

\subsubsection{Cooking-related OA}

The most prominent ions of the resolved COA profile at MK were $m / z 41$ (mainly $\mathrm{C}_{2} \mathrm{HO}^{+}, \mathrm{C}_{3} \mathrm{H}_{5}^{+}$) and $m / z 55$ 

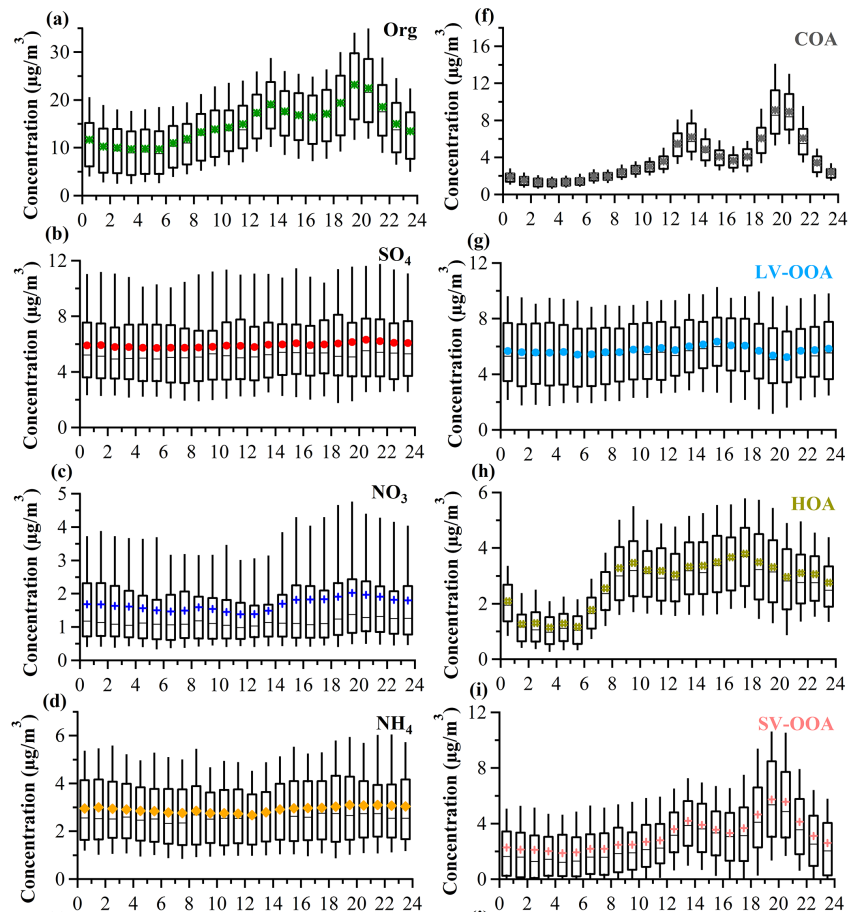

(e) $\begin{array}{lllllllllllll}0 & 2 & 4 & 6 & 8 & 10 & 12 & 14 & 16 & 18 & 20 & 22 & 24\end{array}$

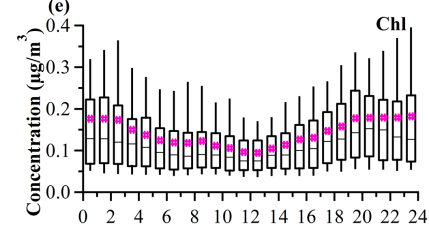

Hour of day
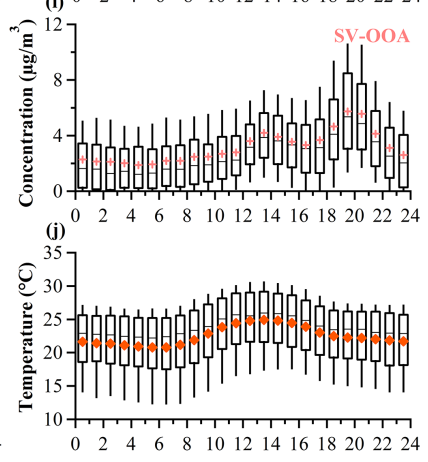

Hour of day

Figure 4. Diurnal profiles of NR-PM 1 species, OA components and temperature for the entire study with 25 th and 75 th percentile boxes, 10th and 90th percentile whiskers, mean as colored marker and median as black line in the whisker box.

(mainly $\mathrm{C}_{3} \mathrm{H}_{3} \mathrm{O}^{+}, \mathrm{C}_{4} \mathrm{H}_{7}^{+}$). Ratios of $m / z 41 / 43=1.8$ and $m / z 55 / 57=2.2$, which are distinctly larger than that of HOA at 0.73 and 0.76 , respectively (Fig. 4); such ratios have been widely reported for COA in AMS and ACSM studies. For example, Lanz et al. (2010) reported ratios of $m / z 41 / 43$ and $m / z 55 / 57$ of 0.5 and 0.4 in HOA and 1.2 and 1.2 in COA, respectively, while Sun et al. (2013a) reported 0.5 for these two ratios in HOA and 2.3 for those in COA, respectively.

Figure 6a shows COA concentrations sorted by wind direction in MK. The COA concentration reaches up to $12 \mu \mathrm{g} \mathrm{m}^{-3}$, contributing $\sim 60 \%$ of total organics, when easterly winds dominate, probably due to the large number of restaurants located on the eastern side of the sampling site (Fig. 6a). In general, COA contributes significantly to the total mass of organic aerosol with an average fraction of $24 \%\left(3.7 \mu \mathrm{g} \mathrm{m}^{-3}\right)$, in line with the $16-30 \%$ COA contributions found in several cities including London, Manchester, Barcelona, Beijing, Fresno and New York (Allen et al., 2010; Huang et al., 2010; Sun et al., 2013b; Mohr et al., 2012; Ge et al., 2012). Figure $6 \mathrm{~b}$ and c compare the chemical
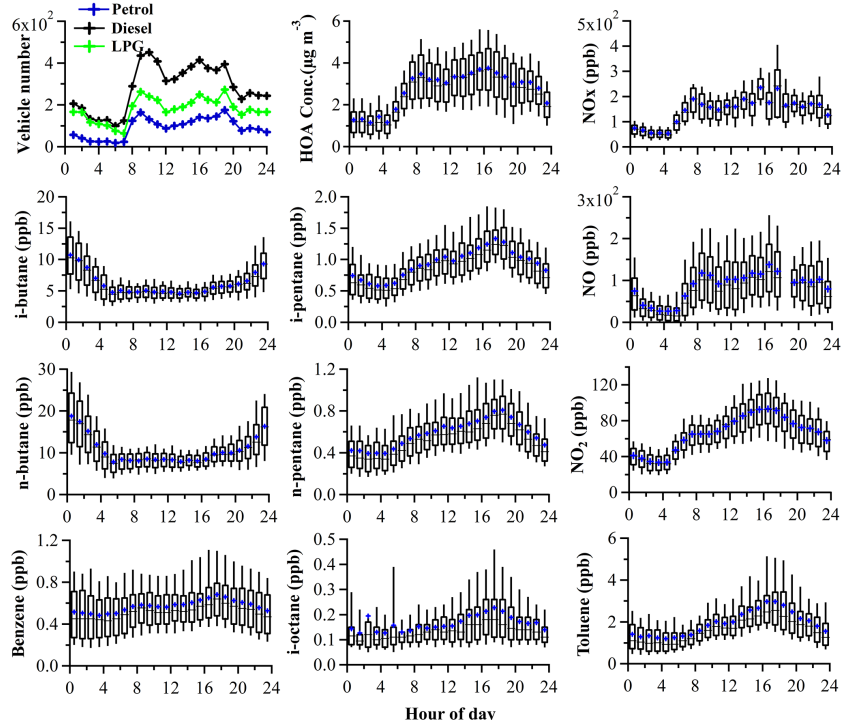

Figure 5. Diurnal patterns of vehicle numbers at the Mong Kok site during 28-31 May 2013 and concentrations of $\mathrm{HOA}, \mathrm{NO}_{x}, \mathrm{NO}_{2}$, NO, i-pentane, n-pentane, i-octane, i-butane, n-butane, benzene and toluene during the whole study.

composition of NR-PM 1 and OA during mealtimes (lunch, 12:00-02:00, and dinner, 19:00-21:00) and non-mealtimes (00:00-06:00); the non-meal period is defined by the periods of low concentration $\left(<2^{-} \mu \mathrm{g} \mathrm{m}^{-3}\right)$ in the COA diurnal pattern. During dinner time, the average concentration of organics increases by about $11 \mu \mathrm{g} \mathrm{m}^{-3}$ and its contributions in total NR-PM $\mathrm{P}_{1}$ increase to $70 \%$, while the concentrations of other species do not change much (Fig. 6b). As shown in Fig. 6c, the increase in organic concentrations results from the increase in COA from 1.7 to $7.8 \mu \mathrm{g} \mathrm{m}^{-3}$ ( $\sim 360 \%$ increase), and to a lesser extent increases in SV-OOA (from 1.5 to $4.5 \mu \mathrm{g} \mathrm{m}^{-3}$, a $\sim 200 \%$ increase) and in HOA (from 1.4 to $3.2 \mu \mathrm{g} \mathrm{m}^{-3}$, a $\sim 130 \%$ increase). As shown in Table 1 , the average concentration of organics during dinner time is $5 \mu \mathrm{g} \mathrm{m}^{-3}$ higher than that during lunch, and this increase is attributed to the increase of COA and SV-OOA mass but not of HOA. This is consistent with the expectation that the cooking activities at MK are higher during dinner than during lunch, while traffic during dinner is comparable to or smaller than that during lunch (Fig. $4 \mathrm{f}$ and $\mathrm{h}$ ). The increase of SV-OOA during dinner time may be the result of enhanced cooking emissions and possibly less evaporation due to lower ambient temperature; contributions from traffic emissions are not likely to be important since there is little increase of HOA during mealtime.

\subsubsection{Oxygenated OA}

LV-OOA is characterized by the prominent $m / z 44$ ion (mainly $\mathrm{CO}_{2}^{+}$) and minor $\mathrm{C}_{n} \mathrm{H}_{2 n-1}$ and $\mathrm{C}_{n} \mathrm{H}_{2 n+1}$ ion series generated by saturated alkanes, alkenes and cycloalkanes. 
(a)

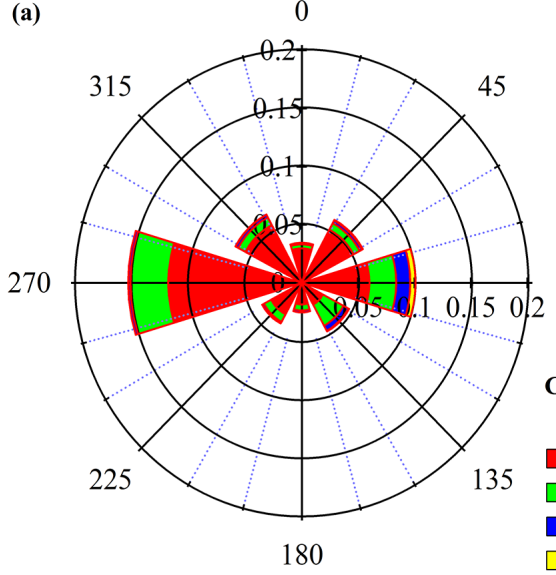

(b)

(c)

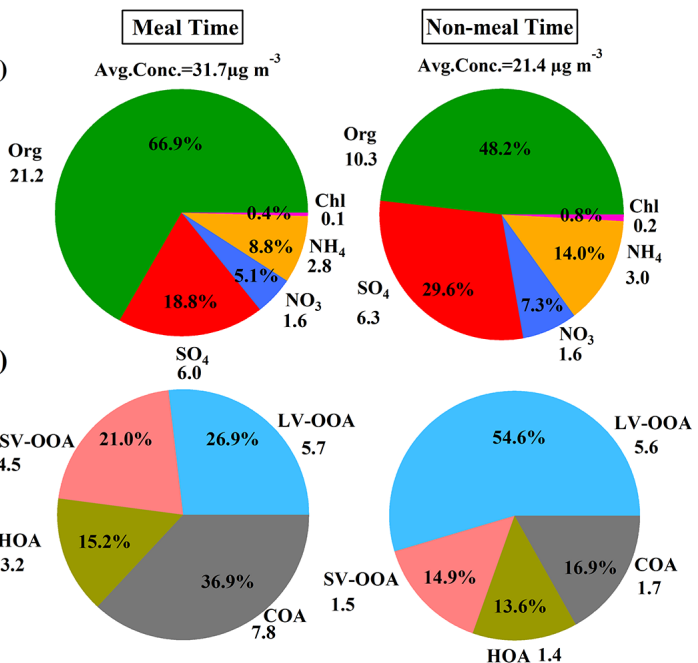

Figure 6. (a) Wind rose plot of COA concentration. The angle and radius present the wind direction and its probability, respectively, while

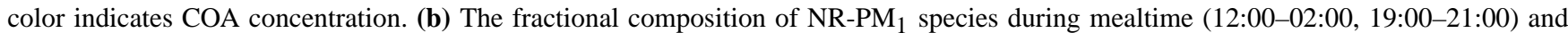
non-mealtime (00:00-06:00). (c) The fractional composition of OA during mealtime and non-mealtime.

Table 1. Average concentrations of NR-PM 1 and OA components during lunch time, dinner time and non-mealtimes.

\begin{tabular}{lrrr}
\hline $\begin{array}{l}\text { Species } \\
\mu \mathrm{g} \mathrm{m}^{-3}\end{array}$ & Lunch & Dinner & Non-meal \\
\hline $\mathrm{Org}$ & 18.8 & 23.7 & 10.3 \\
$\mathrm{SO}_{4}$ & 5.8 & 6.1 & 6.3 \\
$\mathrm{NH}_{4}$ & 2.6 & 2.9 & 3.0 \\
$\mathrm{NO}_{3}$ & 1.4 & 1.8 & 1.6 \\
$\mathrm{Chl}$ & 0.1 & 0.2 & 0.2 \\
\hline \multicolumn{5}{c}{ Organic aerosol components } \\
\hline $\mathrm{HOA}$ & 3.2 & 3.2 & 1.4 \\
$\mathrm{COA}$ & 6.2 & 9.6 & 1.7 \\
$\mathrm{LV}-\mathrm{OOA}$ & 5.8 & 5.4 & 5.6 \\
$\mathrm{SV}-\mathrm{OOA}$ & 3.6 & 5.5 & 1.5 \\
\hline
\end{tabular}

The LV-OOA spectrum correlates well with the standard LVOOA spectrum (Fig. 3), with a $R_{\mathrm{uc}}$ of 0.97 . The LV-OOA time series is associated with that of $\mathrm{SO}_{4}^{2-}$ with a $R_{\mathrm{pr}}$ of 0.86 (Fig. 1), consistent with reports in the literature (DeCarlo et al., 2010; He et al., 2011; Zhang et al., 2014; Tiitta et al., 2014). The LV-OOA diurnal pattern varies little, suggesting that it is part of the background aerosol, possibly resulting from long-range transport ( $\mathrm{Li}$ et al., 2013, 2015).

$\mathrm{SV}-\mathrm{OOA}$, which is less oxidized than LV-OOA, is marked by the dominant ions of $m / z 43$ and $m / z 44$ mainly contributed by $\mathrm{C}_{2} \mathrm{H}_{3} \mathrm{O}^{+}$and $\mathrm{CO}_{2}^{+}$. The mass spectrum of $\mathrm{SV}$ OOA closely resembles that of "standard" SV-OOA with a $R_{\mathrm{uc}}$ of 0.87 (Fig. 3). Some marker fragments of COA and HOA, for example $m / z 41,43,55$ and 57 , are presented in the SV-OOA mass spectrum. SV-OOA concentrations are also
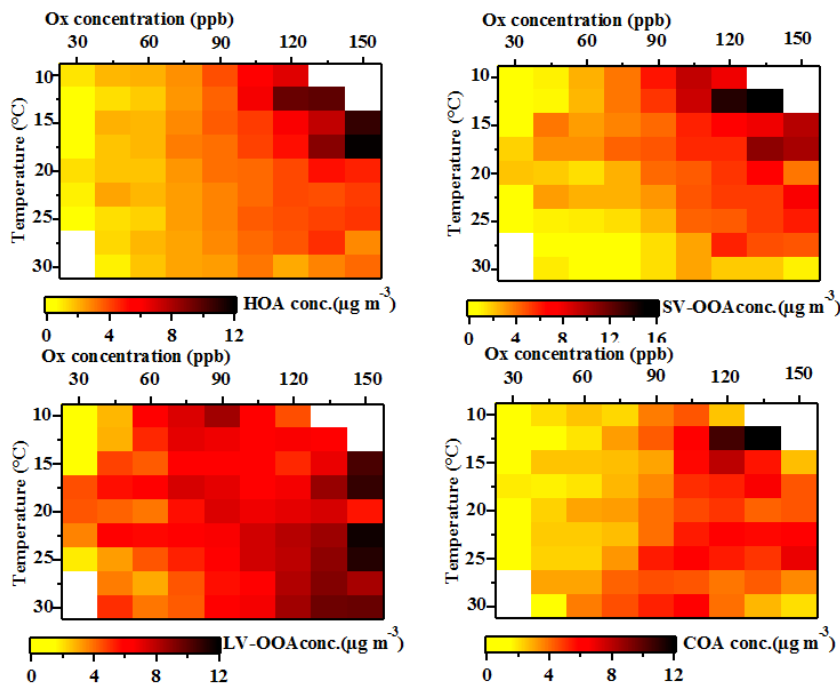

Figure 7. Variation of the average concentration of OA components (HOA, SV-OOA, LV-OOA and COA) coded by color as a function of binned $\mathrm{O}_{x}$ concentration (ppb) and binned temperature $\left({ }^{\circ} \mathrm{C}\right)$.

weakly associated with those of HOA and their co-emitted precursors (benzene and toluene), with $R_{\mathrm{pr}}$ of $0.58,0.65$ and 0.51 , respectively. In fact, the correlation between SV-OOA and benzene is better than that of HOA and benzene (0.56). The diurnal pattern of SV-OOA also shows peaks at mealtimes like COA. Lastly, the fraction of signal at $m / z 44(f 44$ fraction) of SV-OOA at MK is twice that of the standard measured by Q-AMS (Zhang et al., 2014; Tiitta et al., 2014). Together, these results suggest that SV-OOA may be correlated with POA (HOA and COA), possibly due to rapid oxidation of POA to semivolatile gases, which may then form 
Table 2. Regression of SV-OOA on HOA, COA and LV-OOA and concentrations of OA factors and $\mathrm{O}_{x}$ under high and low temperature (LT and HT) of the three chosen periods (MT, BT and OT).

\begin{tabular}{|c|c|c|c|c|c|c|}
\hline \multirow{2}{*}{$\begin{array}{l}\text { Period } \\
\text { Temperature }\end{array}$} & \multicolumn{2}{|c|}{ Mealtime (MT) } & \multicolumn{2}{|c|}{ Background time (BT) } & \multicolumn{2}{|c|}{ Other time (OT) } \\
\hline & LTemp & HTemp & LTemp & HTemp & LTemp & HTemp \\
\hline \multicolumn{7}{|c|}{ Coefficients $^{\mathrm{a}}$} \\
\hline $\mathrm{HOA}$ & 0.80 & 0.56 & 0.70 & 0.43 & 0.48 & 0.23 \\
\hline $\mathrm{COA}$ & 0.29 & 0.15 & 0.22 & 0.00 & 0.31 & 0.11 \\
\hline LV-OOA & 0.25 & 0.23 & 0.23 & 0.24 & 0.25 & 0.28 \\
\hline Adjusted $R^{2}$ & 0.90 & 0.81 & 0.83 & 0.57 & 0.85 & 0.73 \\
\hline \multicolumn{7}{|c|}{ Average concentration $\left(\mu \mathrm{g} \mathrm{m}^{-3}, \mathrm{ppb}\right)$} \\
\hline $\mathrm{HOA}$ & 3.71 & 2.85 & 1.60 & 1.18 & 3.51 & 2.88 \\
\hline $\mathrm{COA}$ & 7.34 & 7.40 & 1.61 & 1.54 & 3.50 & 3.74 \\
\hline LV-OOA & 5.46 & 5.57 & 5.91 & 5.07 & 5.85 & 5.99 \\
\hline SV-OOA & 6.30 & 3.89 & 2.68 & 1.44 & 4.1 & 2.39 \\
\hline $\mathrm{O}_{x}(\mathrm{ppb})$ & 83.12 & 85.23 & 58.71 & 53.45 & 75.06 & 76.77 \\
\hline
\end{tabular}

SV-OOA. However, the variation of the average concentration of SV-OOA as a function of binned LV-OOA concentration in increments and a bin width of $2 \mu \mathrm{g} \mathrm{m}^{-3}$ is shown in Fig. S13. The linear, positive relationship between SV-OOA and LV-OOA suggests that non-local formation and subsequent transport may also contribute to the measured SVOOA at MK. However, it should be mentioned that ACSMresolved organic spectra have been observed to show higher $f 44$ in other studies (Crenn et al., 2015; Frohlich et al., 2015) compared to HR-ToF-AMS measurements due to inherent instrumental uncertainties in the determination of $f 44$. This might have caused the elevated $f 44$ observed in our SV-OOA spectrum.

Figure 7 displays the concentration of different OA factors (coded by color) as a function of binned $\mathrm{O}_{x}$ concentration (ppb) and binned temperature $\left({ }^{\circ} \mathrm{C}\right)$ with a bin width of $15 \mathrm{ppb}$ and $5^{\circ} \mathrm{C}$, respectively. In general, the concentration of all OA factors increases as $\mathrm{O}_{x}$ increases across all temperatures. While it is understood that LV-OOA and SV-OOA are correlated with $\mathrm{O}_{x}$ because they all result from similar photochemical activities, the correlation between HOA and $\mathrm{O}_{x}$ is the result of the good correlation (0.78) between $\mathrm{HOA}$ and $\mathrm{NO}_{2}$, which accounts for $84 \%$ of total $\mathrm{O}_{x} \cdot \mathrm{NO}_{2}$ is partly emitted directly from vehicles and partly formed by secondary oxidation at MK as discussed in Sect. 3.2.1. Increase in ambient temperature is associated with decrease in HOA and SV-OOA, likely due to evaporation effects and partitioning, but it has no obvious correlations with LV-OOA and COA.

To further assess the relative importance of other OA factors to the resolved SV-OOA, ordinary least squares regressions were conducted. Considering the potential influence of primary OA on the regression results, the whole data set was separated into three time periods consisting of mealtime (MT; 12:00-14:00 and 19:00-21:00) marked by enhanced COA, background time (BT; 00:00-06:00) marked by low POA and other time (OT; 06:00-12:00, 14:00-19:00 and 21:00-24:00). The data of each period were further divided into high/low temperature (HTemp, LTemp $\left.=T<22.5^{\circ} \mathrm{C}\right)$ and high/low $\mathrm{O}_{x}\left(\mathrm{HiO}_{x}, \mathrm{LO}_{x}=\mathrm{O}_{x}<70 \mathrm{ppb}\right)$ to reveal impacts of temperature and the degree of oxygenation on the correlations among OA factors.

Tables 2 and 3 show the coefficients of HOA, COA and LV-OOA in the regression equation for the reconstructed SVOOA and their average concentrations during different periods under high/low temperature and high/low $\mathrm{O}_{x}$, respectively. The average concentrations of HOA and SV-OOA under HTemp are obviously lower than under LTemp for each period but the concentration of COA and LV-OOA varies little across different temperatures (Table 2). By combining the stronger correlations between HOA and SV-OOA rather than between COA and SV-OOA, a stronger and closer temperature dependence of HOA and SV-OOA was revealed. In addition, the regression coefficients of HOA and COA during each period under HTemp are much smaller than under LTemp, reflecting a weakening of their relationship with SVOOA as temperature increases.

Consistent with the discussion of Fig. 7, the concentrations of HOA, SV-OOA and LV-OOA except for COA under $\mathrm{HiOx}$ are greatly higher than those under $\mathrm{LOx}$ for each period (Table 3). Besides, HOA shows an increase correlation with SV-OOA under HiOx due to the more intensive oxidation of HOA precursor to SV-OOA. However, LV-OOA shows a reverse trend with smaller coefficients with SV-OOA. It is 


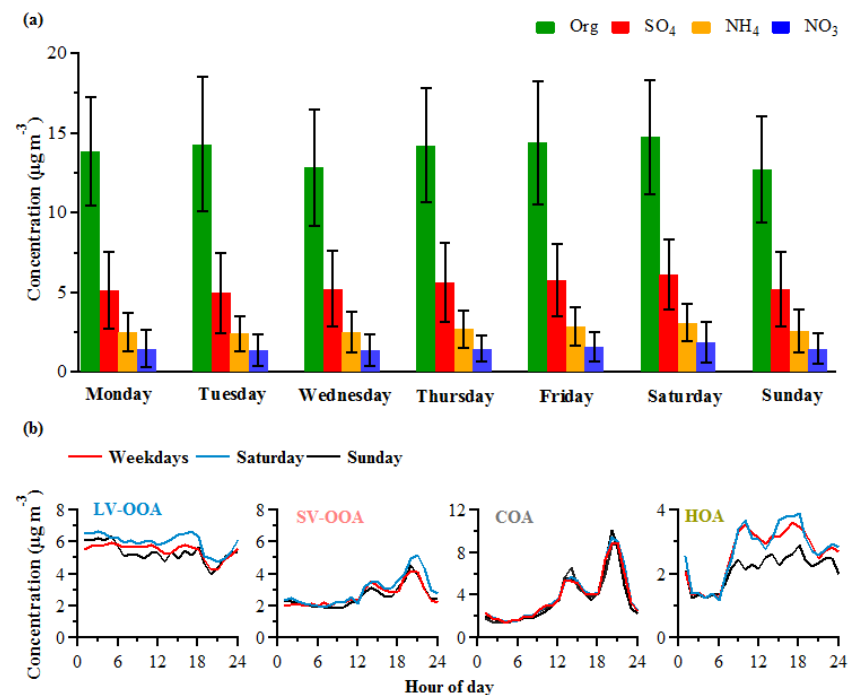

Figure 8. (a) Day-of-week variations of NR-PM 1 species (standard deviation as vertical line) and (b) average diurnal patterns of OA components for weekdays, Saturdays and Sundays.

probable that HiOx conditions favor the conversion of SVOOA to LV-OOA leading to smaller coefficient of LV-OOA on SV-OOA, although overall most LV-OOA is considered to be from transport.

At last, we also can conclude that HOA overall has a stronger relationship to SV-OOA than COA has, supported by much higher coefficients of HOA than that of COA over all time periods, and temperature and $\mathrm{O}_{x}$ levels. Cooking emissions are not as important to SV-OOA in the BT periods but they can be important during MT periods, indicated by the lowest concentration and correlation with SV-OOA during BT but highest concentration during MT periods.

\subsection{Diurnal patterns}

The diurnal profiles of NR-PM $\mathrm{P}_{1}$ species and OA components are depicted in Fig. 4. Total organics display a diurnal pattern with two pronounced peaks during 12:00-14:00 and 19:0021:00, corresponding to the peaks of COA at lunch and dinner time, respectively. In addition, organics increase at about 10:00, which may be related to the increase of local emissions of HOA and COA by 2.3 and $1.1 \mu \mathrm{g} \mathrm{m}^{-3}$, respectively, from 06:00 to 10:00.

The mass concentration of sulfate (Fig. $4 \mathrm{~b}$ ) does not show any diel variation. It is likely that sulfate, as a regional pollutant, is mainly formed during long-range transport, leading to the lack of a specific diurnal pattern at MK; a similar flat diurnal pattern for sulfate has also been found at the HKUST supersite in Hong Kong (Lee et al., 2013; Li et al., 2015). These results differ significantly from observations in Beijing and Lanzhou in China and Welgegund in South Africa (Sun et al., 2012, 2013b; Xu et al., 2014; Tiitta et al., 2014) where sulfate displays an obvious increase at noontime in summer and wet seasons due to either photochemical reaction or aqueous oxidation of $\mathrm{SO}_{2}$. The difference may result from the much lower level of sulfur dioxide $\left(\mathrm{SO}_{2}\right)$ with an average of $4.6 \mathrm{ppb}$ in $\mathrm{MK}$ compared to, for example, $\sim 32$ ppb in Beijing, where coal combustion leads to a much higher $\mathrm{SO}_{2}$ concentration (Lin et al., 2011); sulfate and relative humidity $(\mathrm{RH})$ have almost no correlation $\left(R^{2}=0.06\right)$ in $\mathrm{MK}$, suggesting little importance of local aqueous processing for the formation of sulfate.

Nitrate shows a slight dip around noontime, corresponding to the increase of the ambient temperature (Fig. 4j); evaporative loss of particulate nitrate might outweigh the secondary production of nitrate during this time. The diurnal pattern of ammonium (Fig. 4d) is very similar to that of sulfate, as expected based on their commonly observed association in atmospheric particles. Chloride (Fig. 4e) has rather low concentrations and shows a similar diurnal variation to that of nitrate, likely due to its volatility.

\subsection{Day-of-week patterns}

Figure 8a shows the average concentration trends on indi-

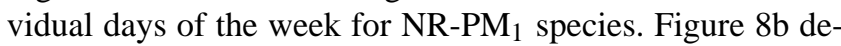
scribes the diurnal patterns of the OA components for weekdays, Saturdays and Sundays, respectively. Because of the small data sets on Saturdays and Sundays, data beyond 1 standard deviation from the mean $\left(25.9 \pm 13.0 \mu \mathrm{g} \mathrm{m}^{-3}\right)$ were removed from the whole data set to remove the influence of episodic events in this analysis. Overall, total NR-PM 1 concentrations have no obvious variation (average variation less than $5 \%$ ) from Monday to Saturday, but they drop by $16 \%$ on Sundays compared to Saturdays. This weekend difference is opposite to the result found in Beijing where higher concentrations occurred on Sundays than Saturdays (Sun et al., 2013b). However, some others such as Lough et al. (2006) and Rattigan et al. (2010) reported that both Saturdays and Sundays had obvious traffic emissions reduction due to less human activities on weekends in Los Angeles and New York, respectively.

Organics and secondary inorganics $\left(\mathrm{SO}_{4}, \mathrm{NH}_{4}\right.$ and $\left.\mathrm{NO}_{3}\right)$ contributed 54 and $46 \%$, respectively, to the concentration difference between Sundays and Saturdays in MK. The difference in organics is mainly attributed to the variation of HOA, which shows very similar diurnal variations on Saturdays and weekdays, but has an average decrease of $23 \%$ after 07:00 on Sundays. A 37\% reduction of traffic-related carbonaceous aerosol on Sundays compared with weekdays in MK has been reported (Huang et al., 2014). In Hong Kong many people work on Saturday, which leads to a traffic pattern similar to normal weekdays. COA shows nearly the same diurnal patterns on all days, and LV-OOA and SV-OOA do not show obvious variations. Overall, local emissions from traffic contribute most to the day-of-week variations in organics. 
Table 3. Regression of SV-OOA on HOA, COA and LV-OOA and concentrations of OA factors and temperature under high and low $\mathrm{O}_{x}$ $\left(\mathrm{HiO}_{x}\right.$ and $\mathrm{LO}_{x}$ ) of four chosen periods (MT, BT and OT).

\begin{tabular}{|c|c|c|c|c|c|c|}
\hline & \multicolumn{2}{|c|}{ Mealtime (MT) } & \multicolumn{2}{|c|}{ Background time (BT) } & \multicolumn{2}{|c|}{ Other time (OT) } \\
\hline & $\mathrm{LO}_{x}$ & $\mathrm{HiO}_{x}$ & $\mathrm{LO}_{x}$ & $\mathrm{HiO}_{x}$ & $\mathrm{LO}_{x}$ & $\mathrm{HiO}_{x}$ \\
\hline \multicolumn{7}{|c|}{ Coefficients $^{\mathrm{a}}$} \\
\hline HOA & 0.50 & 1.13 & 0.62 & $0.64^{\mathrm{b}}$ & $0.08^{\mathrm{b}}$ & 0.52 \\
\hline $\mathrm{COA}$ & 0.13 & 0.14 & 0.00 & 0.15 & 0.14 & 0.14 \\
\hline LV-OOA & 0.33 & $0.10^{\mathrm{b}}$ & 0.26 & 0.18 & 0.34 & 0.21 \\
\hline Adjusted $R^{2}$ & 0.73 & 0.86 & 0.73 & 0.80 & 0.67 & 0.78 \\
\hline \multicolumn{7}{|c|}{ Average concentration $\left(\mu \mathrm{g} \mathrm{m}^{-3}\right)$} \\
\hline $\mathrm{HOA}$ & 2.24 & 3.41 & 1.20 & 2.03 & 2.11 & 3.55 \\
\hline $\mathrm{COA}$ & 7.31 & 7.57 & 1.59 & 1.73 & 2.77 & 3.71 \\
\hline LV-OOA & 3.50 & 5.92 & 5.07 & 7.22 & 4.06 & 6.77 \\
\hline SV-OOA & 3.22 & 5.29 & 1.85 & 2.79 & 1.8 & 3.56 \\
\hline Temp $\left({ }^{\circ} \mathrm{C}\right)$ & 23.30 & 23.80 & 21.48 & 20.39 & 22.01 & 22.74 \\
\hline
\end{tabular}

${ }^{a}$ The coefficient of HOA, COA and LV-OOA in the regression equation reconstructing SV-OOA under $\mathrm{LO}_{x}\left(\mathrm{O}_{x}<70 \mathrm{ppb}\right)$ and $\mathrm{HT}\left(\mathrm{O}_{x}>70 \mathrm{ppb}\right)$ during mealtime $(12: 00-14: 00,19: 00-21: 00)$, background time (00:00-6:00) and other time. The average $\mathrm{O}_{x}$ of the whole study is $70 \mathrm{ppb}$. All entries of coefficients are significant at $1 \%$ level (two-level) except those indicated with ${ }^{\mathrm{b}}$, which indicates significance at the $5 \%$ level.

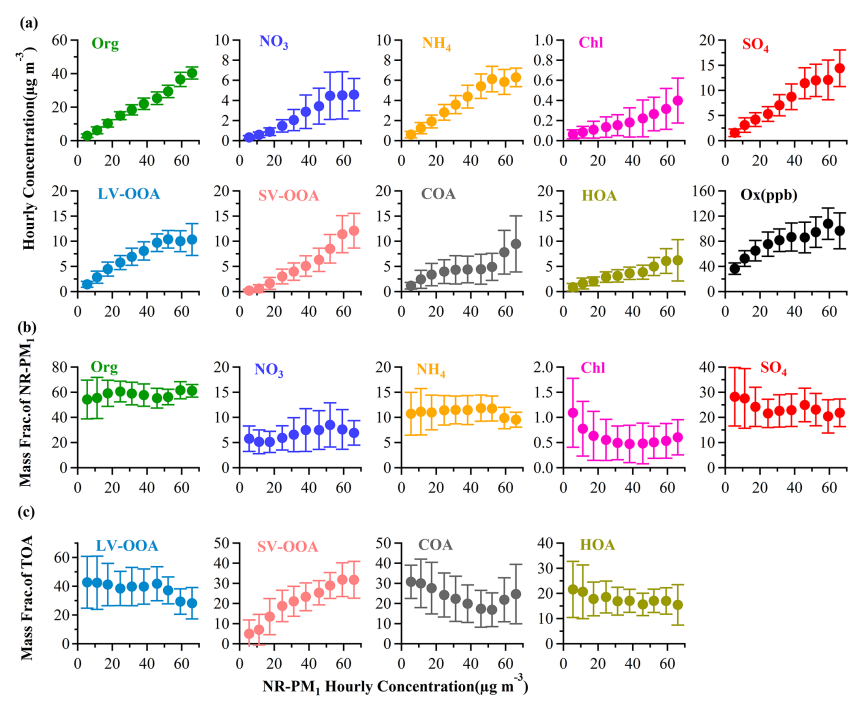

Figure 9. (a) Variations in mass concentration of NR-PM 1 species and OA components as a function of total NR-PM 1 mass loading, and (b) mass fraction of total NR-PM 1 for NR-PM $\mathrm{N}_{1}$ species as a function of total NR-PM 1 mass loading, and (c) mass fraction of total organics for OA components as a function of total NR-PM mass loading. All the mass concentrations and fractions of above species were sorted according to the hourly average NR-PM 1 mass in ascending order. The solid circles represent the average value for each concentration bin with a width of $7 \mu \mathrm{g} \mathrm{m}^{-3}$, and the vertical lines represent the standard deviations.

\subsection{Contributions of individual species and $\mathrm{OA}$ factors to high NR-PM1}

Figure $9 \mathrm{a}, \mathrm{b}$ and $\mathrm{c}$ show the variation in hourly mass concentration of NR-PM $\mathrm{PM}_{1}$ species and OA components and their mass fractions as a function of hourly total NR-PM 1 mass loading, respectively. Below $50 \mu \mathrm{g} \mathrm{m}^{-3}$, all aerosol species display a nearly linear increase with $\mathrm{PM}_{1}$ mass loading, with slopes of about 0.5 for organics, 0.25 for sulfate and LV-OOA and around 0.1 for nitrate, ammonium, COA, HOA and SVOOA (Fig. 9a). While the fractions of $\mathrm{NH}_{4}$ and organics remain relatively stable, sulfate exhibits a decrease and then an increase, and $\mathrm{NO}_{3}$ and chloride show a gradual increase and then a decrease, respectively, as NR-PM 1 increased to $50 \mathrm{\mu g} \mathrm{m}^{-3}$ (Fig. 9b, c). Although the mass concentrations of all organic factors increase as NR-PM 1 increases, SV-OOA is the only factor that increased in mass fraction. Primary OA components (HOA and COA) and transported OA (LV-OOA) show a decrease in fraction and stable contributions, respectively, as NR-PM $M_{1}$ increases to $50 \mu \mathrm{g} \mathrm{m}^{-3}$, while the contribution of SV-OOA increases sharply from around 5 to $25 \%$ of total organic mass. It suggests that SV-OOA plays an important role as NR-PM $\mathrm{PM}_{1}$ increases to $50 \mu \mathrm{g} \mathrm{m}^{-3}$ in MK. However, beyond $50 \mathrm{\mu g} \mathrm{m}^{-3}$, the mass loadings of $\mathrm{SO}_{4}$ and organics increase, while those of $\mathrm{NH}_{4}, \mathrm{NO}_{3}$ and LV-OOA remain almost constant, which differs from the observations in Beijing, where $\mathrm{NH}_{4}$ and $\mathrm{NO}_{3}$ kept a linear increase from 50 to about $200 \mu \mathrm{g} \mathrm{m}^{-3}$ (Sun et al., 2013b; Zhang et al., 2014). In terms of fractions, only COA and, to a lesser extent, SV-OOA increase as NR-PM $\mathrm{PM}_{1}$ increases further. In fact, over $80 \%$ of the high hourly NR-PM ${ }_{1}$ concentrations $\left(>50 \mu \mathrm{g} \mathrm{m}^{-3}\right)$ are 


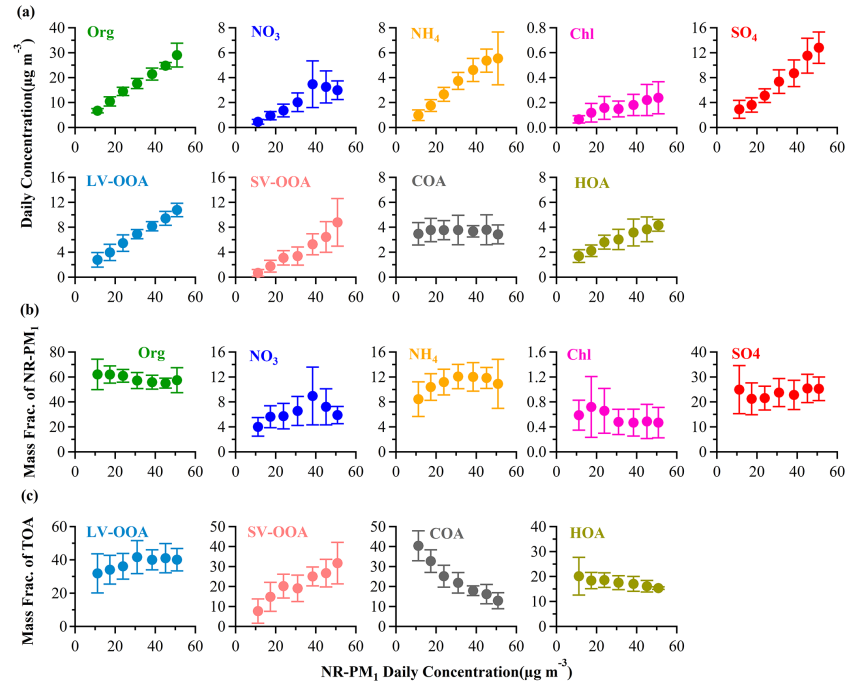

Figure 10. (a) Variation in mass concentration of NR-PM 1 species and OA components as a function of total NR-PM $\mathrm{P}_{1}$ mass loading, and (b) mass fraction of total NR-PM 1 for NR-PM $\mathrm{N}_{1}$ species as a function of total NR-PM 1 mass loading, and (c) mass fraction of total organics for OA components as a function of total NR-PM mass loading. All the mass concentrations and fractions of above species were sorted according to the daily average NR-PM 1 mass in ascending order. The solid circles represent the average values for each concentration bin with a width of $7 \mu \mathrm{g} \mathrm{m}^{-3}$, and the vertical lines represent the standard deviations.

observed during the mealtime periods with enhanced cooking activities.

When the hourly averages in Fig. 9 are replaced by daily averages (Fig. 10), the COA concentration varies little and its fraction does not exhibit an increase but instead decreases

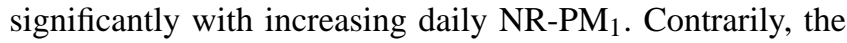
fractions of SV-OOA and LV-OOA clearly increase. This analysis suggests that while cooking OA is responsible for the hourly high concentrations during mealtime and potential high hourly PM levels, LV-OOA/SV-OOA is responsible for episodic events and high day-to-day PM levels.

To analyze the difference in particle composition and meteorological conditions among episodic periods and clean periods, three heavy polluted episodes (19-22, 23-26 October and 10-13 December) and two clean periods (17-18 September and 14-18 December), highlighted in Fig. 1, were analyzed. The average concentrations of these chosen periods are larger than 1 standard deviation from the average concentration of the campaign $\left(25.9 \pm 13.0 \mu \mathrm{g} \mathrm{m}^{-3}\right)$. The composition, meteorological features ( $T$ and $\mathrm{RH})$ and oxidation index $\left(\mathrm{O}_{x}\right.$ and $\left.f 44\right)$ of these five events are shown in Table 4. Clean period $1(\mathrm{C} 1)$ is characterized by low NR-PM 1 concentrations (below $13 \mu \mathrm{g} \mathrm{m}^{-3}$ ), prevailing coastal wind (easterly wind), lack of rain, high ambient temperature $\left(\sim 28^{\circ} \mathrm{C}\right)$ and high relative humidity $(\sim 70 \%)$. Another clean period (C2) features continuous precipitation with the coldest and

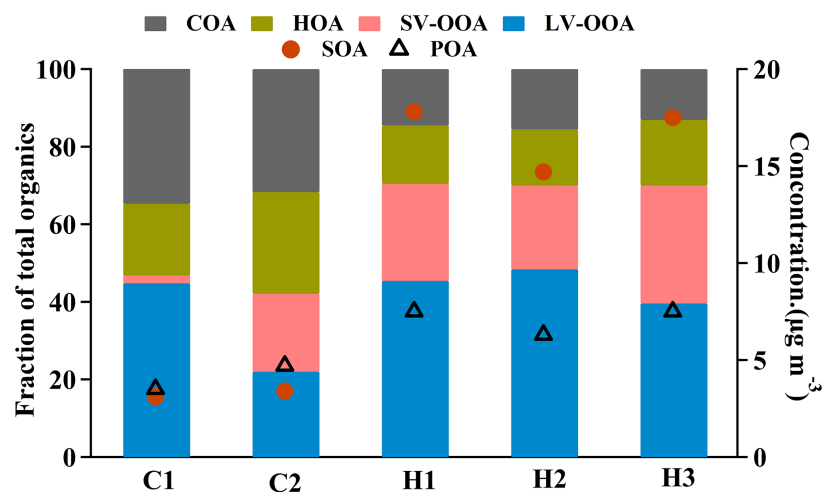

Figure 11. Mass fraction of hydrocarbon-like organic aerosol (HOA), cooking organic aerosol (COA), semi-volatile oxygenated organic aerosol (SV-OOA) and low-volatility oxygenated organic aerosol (LV-OOA) in color, and the mass concentration of POA and SOA marked by triangles and circles, respectively, during five periods: clean periods ( $\mathrm{C} 1$ and $\mathrm{C} 2)$ and haze periods ( $\mathrm{H} 1, \mathrm{H} 2$ and $\mathrm{H} 3$ ).

most humid weather condition in the period studied. Haze period $1(\mathrm{H} 1)$ has similar temperature and humidity as $\mathrm{C} 1$ but is marked by mixed continental/oceanic winds. From $\mathrm{H} 1$ to the following haze period $(\mathrm{H} 2)$, the observed wind direction shifts to reflect continental transport, with a significant decrease in RH to $36 \%$. Haze period 3 (H3), just before $\mathrm{C} 2$, is also dominated by continental winds but with lower temperatures $\left(\sim 19^{\circ} \mathrm{C}\right)$ than during other haze events.

Although the total NR-PM 1 of $\mathrm{C} 1\left(12.2 \mu \mathrm{g} \mathrm{m}^{-3}\right)$ and $\mathrm{C} 2$ $\left(11.8 \mu \mathrm{g} \mathrm{m}^{-3}\right)$ are both only $25-30 \%$ of that during haze periods, they were driven by different mechanisms. The main differences in meteorological conditions between $\mathrm{C} 1$ and $\mathrm{C} 2$ are the dominance of continental wind rather than coastal wind, much lower temperature and the existence of precipitation in $\mathrm{C} 2$. The low concentration of $\mathrm{C} 1$ is mainly attributed to easterly wind bringing less air pollutants and diluting local air pollutants. To a lesser extent, it is influenced by both particle evaporation, especially for SV-OOA, and dilution of local emissions during high temperatures, which might be the reason why HOA, COA and SV-OOA in $\mathrm{C} 1$ are lower than in $\mathrm{C} 2$ despite the lack of rain. The low mass loading of $\mathrm{C} 2$ was mainly caused by the wet deposition of precipitation. It dramatically reduces the concentration of secondary species, such as $\mathrm{SO}_{4}, \mathrm{NH}_{4}, \mathrm{NO}_{3}, \mathrm{SV}-\mathrm{OOA}$ and LV-OOA, but not primary HOA and COA. Compared to the adjacent period $\mathrm{H} 3$, the total organic mass reduces by $68 \%$ to an average of $8.1 \mu \mathrm{g} \mathrm{m}^{-3}$ (Table 4). Precipitation effectively removes secondary particles but is less efficient for primary particles that are continuously generated locally.

With similar continental source region as $\mathrm{C} 2$, the most severe pollution event H3 occurred during 10-13 December with an average NR-PM ${ }_{1}$ of $47.7 \mu \mathrm{g} \mathrm{m}^{-3}$. The persistent northerly wind continually brought air masses from the PRD region into Hong Kong and lead to a marked mass increase of secondary species of $\mathrm{SO}_{4}, \mathrm{NH}_{4}, \mathrm{NO} 3, \mathrm{LV}-\mathrm{OOA}$ and $\mathrm{SV}$ - 
Table 4. Measured and calculated parameters in five chosen periods (C1, H1, H2, H3 and C2).

\begin{tabular}{|c|c|c|c|c|c|c|c|c|c|c|}
\hline & \multicolumn{2}{|c|}{$\begin{array}{l}\text { Clean period } 1 \\
(\mathrm{C} 1)^{\mathrm{a}}\end{array}$} & \multicolumn{2}{|c|}{$\begin{array}{l}\text { Haze period } 1 \\
\qquad(\mathrm{H} 1)\end{array}$} & \multicolumn{2}{|c|}{$\begin{array}{l}\text { Haze period } 2 \\
(\mathrm{H} 2)\end{array}$} & \multicolumn{2}{|c|}{$\begin{array}{l}\text { Haze period } 3 \\
\text { (H3) }\end{array}$} & \multicolumn{2}{|c|}{$\begin{array}{c}\text { Clean period } 2 \\
\text { (C2) }\end{array}$} \\
\hline $\mathrm{RH}(\%)$ & \multicolumn{2}{|c|}{70.8} & \multicolumn{2}{|c|}{65.0} & \multicolumn{2}{|c|}{36.4} & \multicolumn{2}{|c|}{64.8} & \multicolumn{2}{|c|}{84.6} \\
\hline$T\left({ }^{\circ} \mathrm{C}\right)$ & \multicolumn{2}{|c|}{27.6} & \multicolumn{2}{|c|}{25.0} & \multicolumn{2}{|c|}{23.8} & \multicolumn{2}{|c|}{18.7} & \multicolumn{2}{|c|}{13.2} \\
\hline $\mathrm{O}_{x}(\mathrm{ppb})$ & \multicolumn{2}{|c|}{69.6} & \multicolumn{2}{|c|}{82.0} & \multicolumn{2}{|c|}{99.5} & \multicolumn{2}{|c|}{70.4} & \multicolumn{2}{|c|}{40.9} \\
\hline$f 44$ & \multicolumn{2}{|c|}{0.114} & \multicolumn{2}{|c|}{0.118} & \multicolumn{2}{|c|}{0.120} & \multicolumn{2}{|c|}{0.108} & \multicolumn{2}{|c|}{0.057} \\
\hline Precip.(mm) & \multirow{2}{*}{\multicolumn{2}{|c|}{$\begin{array}{c}0 \\
\text { coastal }\end{array}$}} & \multirow{2}{*}{\multicolumn{2}{|c|}{$\begin{array}{c}0 \\
\text { continental/oceanic }\end{array}$}} & \multirow{2}{*}{\multicolumn{2}{|c|}{$\begin{array}{c}0 \\
\text { continental }\end{array}$}} & \multirow{2}{*}{\multicolumn{2}{|c|}{$\begin{array}{c}0 \\
\text { continental }\end{array}$}} & \multirow{2}{*}{\multicolumn{2}{|c|}{$\begin{array}{c}8.9 \\
\text { continental }\end{array}$}} \\
\hline Wind & & & & & & & & & & \\
\hline$\left(\mu \mathrm{g} \mathrm{m}^{-3} \%\right)$ & Conc. & Perc. & Conc. & Perc. & Conc. & Perc. & Conc. & Perc. & Conc. & Perc. \\
\hline NR-PM 1 & 12.2 & & 44.1 & & 39.0 & & 47.7 & & 11.6 & \\
\hline Org & 6.7 & 54.4 & 25.2 & 57.2 & 21.1 & 54.2 & 25.1 & 52.6 & 8.1 & 69.6 \\
\hline $\mathrm{SO}_{4}$ & 3.8 & 31.2 & 11.8 & 26.8 & 12.1 & 30.9 & 11.4 & 23.8 & 1.5 & 12.8 \\
\hline $\mathrm{NH}_{4}$ & 1.2 & 9.9 & 4.4 & 10.1 & 4.4 & 11.3 & 6.5 & 13.6 & 1.1 & 9.4 \\
\hline $\mathrm{NO}_{3}$ & 0.4 & 3.5 & 2.4 & 5.6 & 1.3 & 3.4 & 4.4 & 9.2 & 0.8 & 7.3 \\
\hline Chl & 0.1 & 1.0 & 0.2 & 0.4 & 0.1 & 0.2 & 0.4 & 0.8 & 0.1 & 0.9 \\
\hline $\mathrm{HOA}$ & 1.2 & 18.5 & 3.8 & 15.1 & 3.0 & 14.4 & 4.2 & 16.9 & 2.1 & 26.2 \\
\hline $\mathrm{COA}$ & 2.3 & 34.8 & 3.7 & 14.5 & 3.3 & 15.5 & 3.3 & 13.1 & 2.6 & 31.7 \\
\hline LV-OOA & 3.0 & 44.8 & 11.5 & 45.4 & 10.2 & 48.4 & 9.9 & 39.6 & 1.8 & 22.0 \\
\hline SV-OOA & 0.1 & 2.0 & 6.3 & 25.0 & 4.5 & 21.6 & 7.6 & 30.4 & 1.6 & 20.1 \\
\hline
\end{tabular}

a Average of data from clean days (C1 and C2) and hazy days (H1, H2 and H3). C1: 17-18 September; H1: 19-22 October; H2: 23-26 October; H3: 10-13 December; $\mathrm{C} 2$ : $14-18$ December. $T$ : temperature; $\mathrm{RH}$ : relative humidity; $\mathrm{O}_{x}$ : odd oxygen $\left(\mathrm{O}_{3}+\mathrm{NO}_{2}\right)$ in ppbv;

$f 44$ : fraction of $m / z 44$ in organic mass spectra.

OOA. Furthermore, H3 is characterized by the highest mass concentration and relative contribution of nitrate and SVOOA compared with other haze periods. This is likely due to the average temperature of $\mathrm{H} 3$ being $5-6^{\circ} \mathrm{C}$ lower than that of other haze events. In addition, although all three haze events have very similar $\mathrm{SO}_{4}$ mass loading, there is a $\sim 50 \%$ increase in $\mathrm{NH}_{4}$ concentration during the $\mathrm{H} 3$ episode, consistent with the increase of nitrate in that period.

The other two haze events are adjacent with influence from both continental and oceanic region in $\mathrm{H} 1$ and continental source region in $\mathrm{H} 2$. The mixed pattern of source regions during H1 identified as land-sea breeze (Fig. S14) can redistribute PM pollution over the whole PRD region and accumulate air pollutants effectively (Lo et al., 2006; Chan and Yao, 2008; Lee et al., 2013). The pronounced high concentration of LV-OOA and SV-OOA, jointly contributing $70 \%$ of total organics, reflects the oxidation of primary emissions in the PRD under such cycles, which is also observed at the suburban HKUST site (Lee et al., 2013). The periodic nitrate peaks in $\mathrm{H} 1$ with low concentration in daytime and high concentration in nighttime coincide with temperature changes. During $\mathrm{H} 2$ period, the prevailing wind is northwesterly and there is a sharp decrease in relative humidity. It is interesting to note that the dip in $\mathrm{RH}$ during $\mathrm{H} 2$ coincides with the dip in sulfate, ammonium, nitrate and LV-OOA; this might be caused by decreased aqueous-phase processing and by decreased gasparticle partitioning associated with water uptake under low RH for secondary aerosol particles (Sun et al., 2013a, b).
The fractions of $f 44$ during these three haze occasions are all lower than that at HKUST (Li et al., 2013), which reflects a larger abundance of the less oxygenated POA at the urban MK site. In addition, the POA concentration ( $\mathrm{HOA}+\mathrm{COA})$ does not change much between clean periods and haze periods. However, its relative contribution decreases from about $50 \%$ during clean periods to $30 \%$ during haze events because of the pronounced variation of secondary OA as shown in Fig. 11.

\section{Conclusions}

The characteristics and sources of ambient submicron nonrefractory particulate matter $\left(\mathrm{NR}-\mathrm{PM}_{1}\right)$ were investigated in an urban roadside environment in Hong Kong using an Aerodyne ACSM from September to December, 2013; these are the first ACSM measurements in Hong Kong. Organics and sulfate dominate total $\mathrm{NR}-\mathrm{PM}_{1}$, making up more than 50 and $20 \%$ of measured mass concentration, respectively. PMF analysis of organic aerosol mass spectra yielded four characteristic OA factors: HOA, COA, SV-OOA and LV-OOA. Primary OA factors (HOA and COA) from freshly emission contribute $43 \%$ of total organics, slightly larger than that of LV-OOA, which is generally transported pollutant in this study, with about $37 \%$ of total organics. SV-OOA contributes about $20 \%$ of total organics and is variably correlated with HOA, COA and LV-OOA under different conditions and period of a day. While HOA showed a stronger relationship to 
SV-OOA overall, COA can be an important contributor to SV-OOA during mealtimes. In addition, the transported pollutants reflected by LV-OOA displays a relatively stable correlation with SV-OOA during the different periods (BT, MT and OT).

The mass loadings of traffic-related aerosol (HOA) are consistent with expected traffic count data and correlate well with various vehicle-related VOCs and $\mathrm{NO}_{x}$. Furthermore, HOA, with an average decrease of $23 \%$ after 07:00 on Sundays, contributes most to the lower organic concentrations on Sundays when compared with other days. Cooking aerosol displays a well-defined diurnal variation with lunch- and dinnertime peaks and contributes on average $40 \%$ of total organics during mealtimes; COA is clearly associated with local easterly winds, which coincides with the placement of nearby restaurant.

The contributions of individual species and OA factors to high NR-PM 1 were analyzed based on hourly data and daily data. It suggests that while cooking is responsible for the hourly high concentrations during mealtimes, LV-OOA/SVOOA are responsible for episodic events and high daily PM concentration. Three heavily polluted episodes and two clean periods were recorded during sampling and attributed to different meteorological and circulatory conditions. The analysis of clean periods shows that precipitation has an obvious

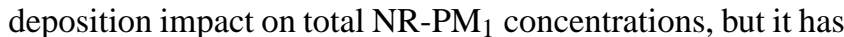
a lesser effect on primary organics. Clean ocean wind not only brings in less polluted air mass but also dilutes the local air pollutants. During this campaign, high-PM events are generally related to continental air mass influence or landsee breeze circulatory conditions, which has less influence on primary emissions but significant effects on secondary particles, with a pronounced increase in the secondary OA contribution during haze events (from 30 to $50 \%$ ).

\section{The Supplement related to this article is available online at doi:10.5194/acp-16-1713-2016-supplement.}

Acknowledgements. The Aerodyne Aerosol Chemical Speciation Monitor measurements were part of the Hong Kong Environmental Protection Department (HKEPD) project ref. 13-00986. EC data were kindly provided by Jianzhen Yu, HKUST. Other data including meteorological data, volatile organic compounds and standard criteria pollutants $\left(\mathrm{NO}_{x}, \mathrm{SO}_{2}\right.$ and $\left.\mathrm{PM}_{2.5}\right)$ were kindly provided by the Hong Kong Environmental Protection Department (HKEPD). Funding support for Berto P. Lee by the Research Grants Council (RGC) of Hong Kong under the Hong Kong PhD Fellowship Scheme (HKPFS) is gratefully acknowledged.

Disclaimer. The opinions expressed in this paper are those of the author and do not necessarily reflect the views or policies of the government of the Hong Kong Special Administrative Region, nor does any mention of trade names or commercial products constitute an endorsement or recommendation of their use.

Edited by: N. L. Ng

\section{References}

Aiken, A. C., DeCarlo, P. F., Kroll, J. H., Worsnop, D. R., Huffman, J. A., Docherty, K. S., Ulbrich, I. M., Mohr, C., Kimmel, J. R., Sueper, D., Sun, Y., Zhang, Q., Trimborn, A., Northway, M., Ziemann, P. J., Canagaratna, M. R., Onasch, T. B., Alfarra, M. R., Prevot, A. S., Dommen, J., Duplissy, J., Metzger, A., Baltensperger, U., and Jimenez, J. L.: O/C and OM/OC Ratios of Primary, Secondary, and Ambient Organic Aerosols with HighResolution Time-of-Flight Aerosol Mass Spectrometry, Environ. Sci. Technol., 42, 4478-4485, doi:10.1021/es703009q, 2008.

Aiken, A. C., Salcedo, D., Cubison, M. J., Huffman, J. A., DeCarlo, P. F., Ulbrich, I. M., Docherty, K. S., Sueper, D., Kimmel, J. R., Worsnop, D. R., Trimborn, A., Northway, M., Stone, E. A., Schauer, J. J., Volkamer, R. M., Fortner, E., de Foy, B., Wang, J., Laskin, A., Shutthanandan, V., Zheng, J., Zhang, R., Gaffney, J., Marley, N. A., Paredes-Miranda, G., Arnott, W. P., Molina, L. T., Sosa, G., and Jimenez, J. L.: Mexico City aerosol analysis during MILAGRO using high resolution aerosol mass spectrometry at the urban supersite (T0) - Part 1: Fine particle composition and organic source apportionment, Atmos. Chem. Phys., 9, 6633-6653, doi:10.5194/acp-9-6633-2009, 2009.

Aiken, A. C., de Foy, B., Wiedinmyer, C., DeCarlo, P. F., Ulbrich, I. M., Wehrli, M. N., Szidat, S., Prevot, A. S. H., Noda, J., Wacker, L., Volkamer, R., Fortner, E., Wang, J., Laskin, A., Shutthanandan, V., Zheng, J., Zhang, R., Paredes-Miranda, G., Arnott, W. P., Molina, L. T., Sosa, G., Querol, X., and Jimenez, J. L.: Mexico city aerosol analysis during MILAGRO using high resolution aerosol mass spectrometry at the urban supersite (T0) Part 2: Analysis of the biomass burning contribution and the non-fossil carbon fraction, Atmos. Chem. Phys., 10, 5315-5341, doi:10.5194/acp-10-5315-2010, 2010.

Allan, J. D., Williams, P. I., Morgan, W. T., Martin, C. L., Flynn, M. J., Lee, J., Nemitz, E., Phillips, G. J., Gallagher, M. W., and Coe, H.: Contributions from transport, solid fuel burning and cooking to primary organic aerosols in two UK cities, Atmos. Chem. Phys., 10, 647-668, doi:10.5194/acp-10-647-2010, 2010.

Bougiatioti, A., Stavroulas, I., Kostenidou, E., Zarmpas, P., Theodosi, C., Kouvarakis, G., Canonaco, F., Prévôt, A. S. H., Nenes, A., Pandis, S. N., and Mihalopoulos, N.: Processing of biomassburning aerosol in the eastern Mediterranean during summertime, Atmos. Chem. Phys., 14, 4793-4807, doi:10.5194/acp-144793-2014, 2014.

Budisulistiorini, S. H., Canagaratna, M. R., Croteau, P. L., Marth, W. J., Baumann, K., Edgerton, E. S., Shaw, S. L., Knipping, E. M., Worsnop, D. R., Jayne, J. T., Gold, A., and Surratt, J. D.: Real-Time Continuous Characterization of Secondary Organic Aerosol Derived from Isoprene Epoxydiols in Downtown Atlanta, Georgia, Using the Aerodyne Aerosol Chemical Speciation Monitor, Environ. Sci. Technol., 47, 5686-5694, doi:10.1021/es400023n, 2013.

Canonaco, F., Crippa, M., Slowik, J. G., Baltensperger, U., and Prévôt, A. S. H.: SoFi, an IGOR-based interface for the efficient use of the generalized multilinear engine (ME-2) for the source 
apportionment: ME-2 application to aerosol mass spectrometer data, Atmos. Meas. Tech., 6, 3649-3661, doi:10.5194/amt6-3649-2013, 2013.

Chan, C. K. and Yao, X. H.: Air pollution in mega cities in China, Atmos. Environ., 42, 1-42, doi:10.1016/j.atmosenv.2007.09.003, 2008.

Cheng, Y., Ho, K. F., Lee, S. C., and Law, S. W.: Seasonal and diurnal variations of PM1.0, PM2.5 and PM10 in the roadside environment of hong kong, China Particuology, 4, 312-315, doi:10.1016/s1672-2515(07)60281-4, 2006.

Cheng, Y., Lee, S. C., Ho, K. F., Chow, J. C., Watson, J. G., Louie, P. K. K., Cao, J. J., and Hai, X.: Chemically-speciated on-road PM2.5 motor vehicle emission factors in Hong Kong, Sci. Total Environ., 408, 1621-1627, doi:10.1016/j.scitotenv.2009.11.061, 2010.

Crenn, V., Sciare, J., Croteau, P. L., Verlhac, S., Fröhlich, R., Belis, C. A., Aas, W., Äijälä, M., Alastuey, A., Artiñano, B., Baisnée, D., Bonnaire, N., Bressi, M., Canagaratna, M., Canonaco, F., Carbone, C., Cavalli, F., Coz, E., Cubison, M. J., Esser-Gietl, J. K., Green, D. C., Gros, V., Heikkinen, L., Herrmann, H., Lunder, C., Minguillón, M. C., Mocnik, G., O’Dowd, C. D., Ovadnevaite, J., Petit, J.-E., Petralia, E., Poulain, L., Priestman, M., Riffault, V., Ripoll, A., Sarda-Estève, R., Slowik, J. G., Setyan, A., Wiedensohler, A., Baltensperger, U., Prévôt, A. S. H., Jayne, J. T., and Favez, O.: ACTRIS ACSM intercomparison - Part 1: Reproducibility of concentration and fragment results from 13 individual Quadrupole Aerosol Chemical Speciation Monitors (Q-ACSM) and consistency with co-located instruments, Atmos. Meas. Tech., 8, 5063-5087, doi:10.5194/amt-8-5063-2015, 2015.

Cubison, M. J., Ortega, A. M., Hayes, P. L., Farmer, D. K., Day, D., Lechner, M. J., Brune, W. H., Apel, E., Diskin, G. S., Fisher, J. A., Fuelberg, H. E., Hecobian, A., Knapp, D. J., Mikoviny, T., Riemer, D., Sachse, G. W., Sessions, W., Weber, R. J., Weinheimer, A. J., Wisthaler, A., and Jimenez, J. L.: Effects of aging on organic aerosol from open biomass burning smoke in aircraft and laboratory studies, Atmos. Chem. Phys., 11, 12049-12064, doi:10.5194/acp-11-12049-2011, 2011.

DeCarlo, P. F., Ulbrich, I. M., Crounse, J., de Foy, B., Dunlea, E. J., Aiken, A. C., Knapp, D., Weinheimer, A. J., Campos, T., Wennberg, P. O., and Jimenez, J. L.: Investigation of the sources and processing of organic aerosol over the Central Mexican Plateau from aircraft measurements during MILAGRO, Atmos. Chem. Phys., 10, 5257-5280, doi:10.5194/acp-10-52572010, 2010.

Fröhlich, R., Crenn, V., Setyan, A., Belis, C. A., Canonaco, F., Favez, O., Riffault, V., Slowik, J. G., Aas, W., Aijälä, M., Alastuey, A., Artiñano, B., Bonnaire, N., Bozzetti, C., Bressi, M., Carbone, C., Coz, E., Croteau, P. L., Cubison, M. J., Esser-Gietl, J. K., Green, D. C., Gros, V., Heikkinen, L., Herrmann, H., Jayne, J. T., Lunder, C. R., Minguillón, M. C., Mocnik, G., O’Dowd, C. D., Ovadnevaite, J., Petralia, E., Poulain, L., Priestman, M., Ripoll, A., Sarda-Estève, R., Wiedensohler, A., Baltensperger, U., Sciare, J., and Prévôt, A. S. H.: ACTRIS ACSM intercomparison - Part 2: Intercomparison of ME-2 organic source apportionment results from 15 individual, co-located aerosol mass spectrometers, Atmos. Meas. Tech., 8, 2555-2576, doi:10.5194/amt8-2555-2015, 2015.
Ge, X., Setyan, A., Sun, Y., and Zhang, Q.: Primary and secondary organic aerosols in Fresno, California during wintertime: Results from high resolution aerosol mass spectrometry, J. Geophys. Res., 117, D19301, doi:10.1029/2012jd018026, 2012.

He, L.-Y., Lin, Y., Huang, X.-F., Guo, S., Xue, L., Su, Q., Hu, M., Luan, S.-J., and Zhang, Y.-H.: Characterization of highresolution aerosol mass spectra of primary organic aerosol emissions from Chinese cooking and biomass burning, Atmos. Chem. Phys., 10, 11535-11543, doi:10.5194/acp-10-11535-2010, 2010.

He, L. Y., Huang, X. F., Xue, L., Hu, M., Lin, Y., Zheng, J., Zhang, R., and Zhang, Y. H.: Submicron aerosol analysis and organic source apportionment in an urban atmosphere in Pearl River Delta of China using high-resolution aerosol mass spectrometry, J. Geophys. Res., 116, D12304, doi:10.1029/2010jd014566, 2011.

Huang, D. D., Li, Y. J., Lee, B. P., and Chan, C. K.: Analysis of Organic Sulfur Compounds in Atmospheric Aerosols at the HKUST Supersite in Hong Kong Using HR-ToF-AMS, Environ. Sci. Technol., 49, 3672-3679, doi:10.1021/es5056269, 2015.

Huang, X.-F., He, L.-Y., Hu, M., Canagaratna, M. R., Sun, Y., Zhang, Q., Zhu, T., Xue, L., Zeng, L.-W., Liu, X.-G., Zhang, Y.-H., Jayne, J. T., Ng, N. L., and Worsnop, D. R.: Highly time-resolved chemical characterization of atmospheric submicron particles during 2008 Beijing Olympic Games using an Aerodyne High-Resolution Aerosol Mass Spectrometer, Atmos. Chem. Phys., 10, 8933-8945, doi:10.5194/acp-10-8933-2010, 2010.

Huang, X.-F., He, L.-Y., Hu, M., Canagaratna, M. R., Kroll, J. H., Ng, N. L., Zhang, Y.-H., Lin, Y., Xue, L., Sun, T.-L., Liu, X.-G., Shao, M., Jayne, J. T., and Worsnop, D. R.: Characterization of submicron aerosols at a rural site in Pearl River Delta of China using an Aerodyne High-Resolution Aerosol Mass Spectrometer, Atmos. Chem. Phys., 11, 1865-1877, doi:10.5194/acp-11-18652011, 2011.

Huang, X. H. H., Bian, Q. J., Louie, P. K. K., and Yu, J. Z.: Contributions of vehicular carbonaceous aerosols to $\mathrm{PM}_{2.5}$ in a roadside environment in Hong Kong, Atmos. Chem. Phys., 14, 92799293, doi:10.5194/acp-14-9279-2014, 2014.

Huang, Y., Ho, S. S. H., Ho, K. F., Lee, S. C., Yu, J. Z., and Louie, P. K. K.: Characteristics and health impacts of VOCs and carbonyls associated with residential cooking activities in Hong Kong, J. Hazard. Mater., 186, 344-351, doi:10.1016/j.jhazmat.2010.11.003, 2011.

Jimenez, J. L., Canagaratna, M. R., Donahue, N. M., Prevot, A. S. H., Zhang, Q., Kroll, J. H., DeCarlo, P. F., Allan, J. D., Coe, H., Ng, N. L., Aiken, A. C., Docherty, K. S., Ulbrich, I. M., Grieshop, A. P., Robinson, A. L., Duplissy, J., Smith, J. D., Wilson, K. R., Lanz, V. A., Hueglin, C., Sun, Y. L., Tian, J., Laaksonen, A., Raatikainen, T., Rautiainen, J., Vaattovaara, P., Ehn, M., Kulmala, M., Tomlinson, J. M., Collins, D. R., Cubison, M. J., Dunlea, J., Huffman, J. A., Onasch, T. B., Alfarra, M. R., Williams, P. I., Bower, K., Kondo, Y., Schneider, J., Drewnick, F., Borrmann, S., Weimer, S., Demerjian, K., Salcedo, D., Cottrell, L., Griffin, R., Takami, A., Miyoshi, T., Hatakeyama, S., Shimono, A., Sun, J. Y, Zhang, Y. M., Dzepina, K., Kimmel, J. R., Sueper, D., Jayne, J. T., Herndon, S. C., Trimborn, A. M., Williams, L. R., Wood, E. C., Middlebrook, A. M., Kolb, C. E., Baltensperger, U., and Worsnop, D. R.: Evolution of Or- 
ganic Aerosols in the Atmosphere, Science, 326, 1525-1529, doi:10.1126/science.1180353, 2009.

Lanz, V. A., Prévôt, A. S. H., Alfarra, M. R., Weimer, S., Mohr, C., DeCarlo, P. F., Gianini, M. F. D., Hueglin, C., Schneider, J., Favez, O., D'Anna, B., George, C., and Baltensperger, U.: Characterization of aerosol chemical composition with aerosol mass spectrometry in Central Europe: an overview, Atmos. Chem. Phys., 10, 10453-10471, doi:10.5194/acp-10-10453-2010, 2010.

Lee, B. P., Li, Y. J., Yu, J. Z., Louie, P. K. K., and Chan, C. K.: Physical and chemical characterization of ambient aerosol by HR-ToFAMS at a suburban site in Hong Kong during springtime 2011, J. Geophys. Res., 118, 8625-8639, doi:10.1002/jgrd.50658, 2013.

Lee, B. P., Li, Y. J., Yu, J. Z., Louie, P. K. K., and Chan, C. K.: Characteristics of submicron particulate matter at the urban roadside in downtown Hong Kong - overview of 4 months of continuous high-resolution aerosol mass spectrometer (HR-AMS) measurements, J. Geophys. Res., 120, 7040-7058, doi:10.1002/2015JD023311, 2015.

Li, Y. J., Lee, B. Y. L., Yu, J. Z., Ng, N. L., and Chan, C. K.: Evaluating the degree of oxygenation of organic aerosol during foggy and hazy days in Hong Kong using high-resolution time-offlight aerosol mass spectrometry (HR-ToF-AMS), Atmos. Chem. Phys., 13, 8739-8753, doi:10.5194/acp-13-8739-2013, 2013.

Li, Y. J., Lee, B. P., Su, L., Fung, J. C. H., and Chan, C.K.: Seasonal characteristics of fine particulate matter (PM) based on highresolution time-of-flight aerosol mass spectrometric (HR-ToFAMS) measurements at the HKUST Supersite in Hong Kong, Atmos. Chem. Phys., 15, 37-53, doi:10.5194/acp-15-37-2015, 2015

Lin, W., Xu, X., Ge, B., and Liu, X.: Gaseous pollutants in Beijing urban area during the heating period 2007-2008: variability, sources, meteorological, and chemical impacts, Atmos. Chem. Phys., 11, 8157-8170, doi:10.5194/acp-11-8157-2011, 2011.

Lo, J. C. F., Lau, A. K. H., Fung, J. C. H., and Chen, F.: Investigation of enhanced cross-city transport and trapping of air pollutants by coastal and urban land-sea breeze circulations, J. Geophys. Res., 111, D14104, doi:10.1029/2005jd006837, 2006.

Lough, G. C., Schauer, J. J., and Lawson, D. R.: Dayof-week trends in carbonaceous aerosol composition in the urban atmosphere, Atmos. Environ., 40, 4137-4149, doi:10.1016/j.atmosenv.2006.03.009, 2006.

Louie, P. K. K., Chow, J. C., Chen, L. W. Antony, W., John, G., Leung, G., and Sin, D. W. M.: PM2.5 chemical composition in Hong Kong: urban and regional variations, Sci. Total Environ., 338, 267-281, doi:10.1016/j.scitotenv.2004.07.021, 2005.

Minguillón, M. C., Ripoll, A., Pérez, N., Prévôt, A. S. H., Canonaco, F., Querol, X., and Alastuey, A.: Chemical characterization of submicron regional background aerosols in the western Mediterranean using an Aerosol Chemical Speciation Monitor, Atmos. Chem. Phys., 15, 6379-6391, doi:10.5194/acp-15-63792015, 2015.

Mohr, C., DeCarlo, P. F., Heringa, M. F., Chirico, R., Slowik, J. G., Richter, R., Reche, C., Alastuey, A., Querol, X., Seco, R., Peñuelas, J., Jiménez, J. L., Crippa, M., Zimmermann, R., Baltensperger, U., and Prévôt, A. S. H.: Identification and quantification of organic aerosol from cooking and other sources in Barcelona using aerosol mass spectrometer data, Atmos. Chem. Phys., 12, 1649-1665, doi:10.5194/acp-12-1649-2012, 2012.
Ng, N. L., Herndon, S. C., Trimborn, A., Canagaratna, M. R., Croteau, P. L., Onasch, T. B., Sueper, D., Worsnop, D. R., Zhang, Q., Sun, Y. L., and Jayne, J. T.: An Aerosol Chemical Speciation Monitor (ACSM) for Routine Monitoring of the Composition and Mass Concentrations of Ambient Aerosol, Aerosol Sci. Tech., 45, 780-794, doi:10.1080/02786826.2011.560211, 2011.

Nie, W., Wang, T., Wang, W., Wei, X., and Liu, Q.: Atmospheric concentrations of particulate sulfate and nitrate in Hong Kong during 1995-2008: Impact of local emission and super-regional transport, Atmos. Environ., 76, 43-51, doi:10.1016/j.atmosenv.2012.07.001, 2013.

Paatero, P. and Tapper, U.: Positive matrix factorization: A non-negative factor model with optimal utilization of error estimates of data values, Environmetrics, 5, 111-126, doi:10.1002/env.3170050203, 1994.

Petit, J.-E., Favez, O., Sciare, J., Crenn, V., Sarda-Estève, R., Bonnaire, N., Mocnik, G., Dupont, J.-C., Haeffelin, M., and LeozGarziandia, E.: Two years of near real-time chemical composition of submicron aerosols in the region of Paris using an Aerosol Chemical Speciation Monitor (ACSM) and a multiwavelength Aethalometer, Atmos. Chem. Phys., 15, 2985-3005, doi:10.5194/acp-15-2985-2015, 2015.

Rattigan, O. V., Dirk Felton, H., Bae, M. S., Schwab, J. J., and Demerjian, K. L.: Multi-year hourly PM2.5 carbon measurements in New York: Diurnal, day of week and seasonal patterns, Atmos. Environ., 44, 2043-2053, doi:10.1016/j.atmosenv.2010.01.019, 2010.

Ripoll, A., Minguillón, M. C., Pey, J., Jimenez, J. L., Day, D. A., Sosedova, Y., Canonaco, F., Prévôt, A. S. H., Querol, X., and Alastuey, A.: Long-term real-time chemical characterization of submicron aerosols at Montsec (southern Pyrenees, $1570 \mathrm{~m}$ a.s.1.), Atmos. Chem. Phys., 15, 2935-2951, doi:10.5194/acp-152935-2015, 2015.

Salcedo, D., Onasch, T. B., Dzepina, K., Canagaratna, M. R., Zhang, Q., Huffman, J. A., DeCarlo, P. F., Jayne, J. T., Mortimer, P., Worsnop, D. R., Kolb, C. E., Johnson, K. S., Zuberi, B., Marr, L. C., Volkamer, R., Molina, L. T., Molina, M. J., Cardenas, B., Bernabé, R. M., Márquez, C., Gaffney, J. S., Marley, N. A., Laskin, A., Shutthanandan, V., Xie, Y., Brune, W., Lesher, R., Shirley, T., and Jimenez, J. L.: Characterization of ambient aerosols in Mexico City during the MCMA-2003 campaign with Aerosol Mass Spectrometry: results from the CENICA Supersite, Atmos. Chem. Phys., 6, 925-946, doi:10.5194/acp-6-925-2006, 2006.

Sun, Y. L., Wang, Z. F., Dong, H. B., Yang, T., Li, J., Pan, X., Chen, P., and Jayne, J. T.: Characterization of summer organic and inorganic aerosols in Beijing, China with an Aerosol Chemical Speciation Monitor, Atmos. Environ., 51, 250-259, doi:10.1016/j.atmosenv.2012.01.013, 2012.

Sun, Y. L., Wang, Z. F., Fu, P. Q., Jiang, Q., Yang, T., Li, J., and Ge, $\mathrm{X}$. : The impact of relative humidity on aerosol composition and evolution processes during wintertime in Beijing, China, Atmos. Environ., 77, 927-934, doi:10.1016/j.atmosenv.2013.06.019, 2013a.

Sun, Y. L., Wang, Z. F., Fu, P. Q., Yang, T., Jiang, Q., Dong, H. B., Li, J., and Jia, J. J.: Aerosol composition, sources and processes during wintertime in Beijing, China, Atmos. Chem. Phys., 13, 4577-4592, doi:10.5194/acp-13-4577-2013, 2013 b. 
Takahama, S., Johnson, A., Guzman Morales, J., Russell, L. M., Duran, R., Rodriguez, G., Zheng, J., Zhang, R., ToomSauntry, D., and Leaitch, W. R.: Submicron organic aerosol in Tijuana, Mexico, from local and Southern California sources during the CalMex campaign, Atmos. Environ., 70, 500-512, doi:10.1016/j.atmosenv.2012.07.057, 2013.

Tiitta, P., Vakkari, V., Croteau, P., Beukes, J. P., van Zyl, P. G., Josipovic, M., Venter, A. D., Jaars, K., Pienaar, J. J., Ng, N. L., Canagaratna, M. R., Jayne, J. T., Kerminen, V.-M., Kokkola, H., Kulmala, M., Laaksonen, A., Worsnop, D. R., and Laakso, L.: Chemical composition, main sources and temporal variability of PM1 aerosols in southern African grassland, Atmos. Chem. Phys., 14, 1909-1927, doi:10.5194/acp-14-1909-2014, 2014.

Ulbrich, I. M., Canagaratna, M. R., Zhang, Q., Worsnop, D. R., and Jimenez, J. L.: Interpretation of organic components from Positive Matrix Factorization of aerosol mass spectrometric data, Atmos. Chem. Phys., 9, 2891-2918, doi:10.5194/acp-9-2891-2009, 2009.

Wanna, L., Hathairatana, G., Wongpun, L., and Kunio, Y.: Ambient Air Concentrations of Benzene, Toluene, Ethylbenzene and Xylene in Bangkok, Thailand during April-August in 2007, Asian Journal of Atmospheric Environment, 2, 14-25, doi:10.5572/ajae.2008.2.1.014, 2008.

Wang, X., Williams, B. J., Wang, X., Tang, Y., Huang, Y., Kong, L., Yang, X., and Biswas, P.: Characterization of organic aerosol produced during pulverized coal combustion in a drop tube furnace, Atmos. Chem. Phys., 13, 10919-10932, doi:10.5194/acp13-10919-2013, 2013.

Wong, T. W., Tam, W. W. S., Yu, I. T. S., Lau, A. K. H., Pang, S. W., and Wong, A. H. S.: Developing a riskbased air quality health index, Atmos. Environ., 76, 52-58, doi:10.1016/j.atmosenv.2012.06.071, 2013.
Xu, J., Zhang, Q., Chen, M., Ge, X., Ren, J., and Qin, D.: Chemical composition, sources, and processes of urban aerosols during summertime in northwest China: insights from high-resolution aerosol mass spectrometry, Atmos. Chem. Phys., 14, 12593 12611, doi:10.5194/acp-14-12593-2014, 2014.

Yuan, Z. B., Yu, J. Z., Lau, A. K. H., Louie, P. K. K., and Fung, J. C. H.: Application of positive matrix factorization in estimating aerosol secondary organic carbon in Hong Kong and its relationship with secondary sulfate, Atmos. Chem. Phys., 6, 25-34, doi:10.5194/acp-6-25-2006, 2006.

Yuan, Z. B., Yadav, V., Turner, J. R., Louie, P. K. K., and Lau, A. K. H.: Long-term trends of ambient particulate matter emission source contributions and the accountability of control strategies in Hong Kong over 1998-2008, Atmos. Environ., 76, 21-31, doi:10.1016/j.atmosenv.2012.09.026, 2013.

Zhang, Q., Alfarra, M. R., Worsnop, D. R., Allan, J. D., Coe, H., Canagaratna, M. R., and Jimenez, J. L.: Deconvolution and Quantification of Hydrocarbon-like and Oxygenated Organic Aerosols Based on Aerosol Mass Spectrometry, Environ. Sci. Technol., 39, 4938-4952, doi:10.1021/es0485681, 2005.

Zhang, Q., Jimenez, J. L., Canagaratna, M. R., Ulbrich, I. M., Ng, N. L., Worsnop, D. R., and Sun, Y.: Understanding atmospheric organic aerosols via factor analysis of aerosol mass spectrometry: a review, Analyt. Bioanalyt. Chem., 401, 3045-3067, doi:10.1007/s00216-011-5355-y, 2011.

Zhang, Y. M., Zhang, X. Y., Sun, J. Y., Hu, G. Y., Shen, X. J., Wang, Y. Q., Wang, T. T., Wang, D. Z., and Zhao, Y.: Chemical composition and mass size distribution of PM1 at an elevated site in central east China, Atmos. Chem. Phys., 14, 12237-12249, doi:10.5194/acp-14-12237-2014, 2014. 